DOI: https://doi.org/10.31933/jemsi.v2i3

Received: 30 November2020, Revised: 25 Desember 2020, Publish: 8 Februari 2021

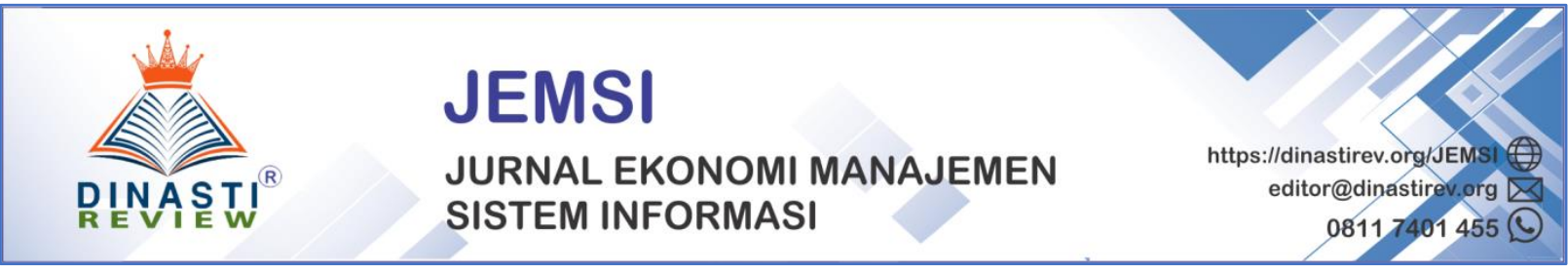

\title{
ANALISIS KOMPARATIF LAPORAN KEUANGAN PT GUDANG GARAM TBK. DENGANINDUSTRI TOBACCO YANG TERDAFTAR DI BURSA EFEK INDONESIA PERIODE 2014-2019
}

\section{Lesta Christina}

Program Studi Magister Manajemen Universitas Mercu Buana, Jakarta, christineesiagian94@ gmail.com

Corresponding Author: Rachella Kezia

Abstrak: Laporan keuangan pada dasarnya adalah hasil dari proses akuntansi yang dapat digunakan sebagai alat untuk berkomunikasi antara data keuangan aktivitas suatu perusahaan dengan pihak-pihak yang berkepentingan. Dengan mengadakan analisis terhadap pos-pos neraca akan dapat diketahui gambaran tentang posisi keuangannya, sedangkan analisis terhadap laporan laba ruginya akan memberikan gambaran mengenai hasil atau perkembangan usaha perusahaan yang bersangkutan. Penelitian dilakukan pada PT Gudang Garam Tbk. PT Gudamng Garam Tbk. merupakan perusahaan yang bergerak dalam bidang industri rokok. Dalam penyusunan laporan keuangan periode yang digunakan yaitu data 2014 - 2019 yang terd aftar di Bursa Efek Indonesia. Metode yang digunakan dalam penelitian ini adalah metode Statistik Deskriptif dan analisis perusahaan. Dari hasil analisis terhadap laporan keuangan PT Gudang Garam Tbk. penulis dapat menilai kondisi kinerja keuangan perusahaan dengan tepat tetapi masih ada keterbatasan dalam analisis rasio tersebut. Kinerja keuangan perusahaan periode tahun 2014-2019 melalui analisis likuiditas, leverage, aktivitas, dan profitabilitas periode terbaik dan terburuk dapat diketahui.

Kata kunci : Rasio Keuangan, Du Pont.

\section{PENDAHULUAN}

Dana Moneter Internasional (IMF) memproyeksi perekonomiann global bakal mengalami kontraksi yang lebih dalam dari prediksi yang sebelumnya. Sebelumnya IMF menyatakan perekonomial dunia akan mengalami krisis keuangan terburuk sejak Depresi Besar Tahun 1930an, perekonomial dunia diproyeksi bakal mengalami kontraksi hingga 3 persen pada 2020. Untuk pertama kalinya sejak Depresi Besar, baik negera berkembang maupun negara maju akan mengalami resesi di tahun 2020. Dalam Outlook Perekonomial Dunia pertumbuhan ekonomi nampaknya akan jauh lebih buruk jika dibandingkan dengan prediksi yang sebelumnya sudah dilakukan. Sebelumnya dalam laporan terbaru Organisasi Kerja Sama dan Pembangunan Ekonomi (OECD) memproyeksi pertumbuhan ekonomi global tahun ini terkontraksi alias minus 6 hingga 7,6 persen.

Di Indonesia sendiri dimana pemerintah akhirnya mengakui bahwa ekonomi Indonesia mengalami resesi. Kendati demikian Kepala Badan Kebijakan Fiskal (BKF) Kementrian 
Keuangan Febrio Kacaribu menjelaskan indikasi pelemahan ekonomi memang sudah tampak sejak awal tahun. BPS sebelumnya mengumumkan pertumbuhan ekonomi Ind onesia di Triwulan III-2020 tumbuh negatif 3,4\% dibandingkan periode yang sama tahun sebelumnya (YoY). Ini merupakan ekonomi tumbuh negatif 5,32\%. Olekarena itu Persaingan yang semakin kompetitif membuat perusahaan-perusahaan harus memaksimalkan sumber daya yang dimiliki guna mencapai tujuan organisasi. Kondisi keuangan dan hasil operasi (kinerja) perusahaan yang tercermin pada laporan keuangan perusahaan yang pada hakikatnya merupakan hasil dari kegiatan akuntansi perusahaan.

Kegiatan dalam analisis laporan keuangan dapat dilakukan dengan menentukan dan mengukur antara antara pos-pos yang ada dalam laporan keuangan. Kemudian, analisis laporan keuangan juga dapat dilakukan dengan menganalisis laporan keuangan yang dimiliki dalam satu periode atau beberapa periode (misalnya 3 tahun). Para pemakai laporan keuangan akan menggunkan untuk meramalkan, membamdingkan, dan menilai dampak keuangan yang timbul karena keputusan ekonomis yang telah diambil. Ada beberapa manfaat analisis laporan keuangan bagi perusahaan. Untuk mengetahui posisi keuangan perusahaan dalam satn periode tertentu, baik harta, kewajiban, modal, maupun hasil yang dicapai untuk beberapa periode, untuk mengetahui kelemahan dan kekuatan apa yang dimiliki perusahaan, untuk mengetahui langkahlangkah perbaikan apa saja yang perlu dilakukan ke depan yang berkaitan dengan posisi keuangan perusahaan saat ini dan untuk melakukan penelitian kinerja manajemen ke depan apakah perlu penyegaran atau tidak karena sudah dianggap berhasil serta dapat digunakan sebagai pembanding dengan perusahaan sejenis tentang hasil yang telah mereka capai.

Dari beberapa manfaat yang ada dapat diketahui bahwa analisis laporan perusahaan sangat perlu dilakukan agar perusahaan dapat berjalan dengan baik. Apabila analisis terhadap laporan keuangan tidak dilakukan, mungkin perusahaan akan mengalami beberapa masalah dalam menentukan langkah kedepannya.Sehingga dari beberapa sumber referensi serta tujuan pembuatan laporan keuangan yang dijelaskan, maka secara garis besar tujuan laporan keuangan adalah untuk memberikan informasi keuangan dalam sebuah perusahaan yang dapat digunakan untuk mengetahui kinerja perusahaan yang akan digunakan untuk pengambilan keputusan oleh manajemen dimasa yang akan datang.

Dari penjelasan referensi yang sudah dijelaskan maka dirancang tujuan yang dilakukan melalui pengukuran kinerja keungan perusahaan. Berikut adalah Laporan Laba-Rugi yang diperoleh oleh PT. Gudang Garam Tbk. selama enam tahun terakhir yang dapat dilihat pada tabel 1. 
Tabel 1 Laporan Laba - Rugi (dalam Miliar Rupiah)

\begin{tabular}{|l|r|r|r|r|r|r|}
\hline & \multicolumn{5}{|c|}{ TAHUN } \\
\hline \multicolumn{1}{|c|}{ NAMA AKUN } & \multicolumn{1}{|c|}{$\mathbf{2 0 1 4}$} & $\mathbf{2 0 1 5}$ & \multicolumn{1}{c|}{$\mathbf{2 0 1 6}$} & $\mathbf{2 0 1 7}$ & \multicolumn{1}{c|}{$\mathbf{2 0 1 8}$} & \multicolumn{1}{c|}{$\mathbf{2 0 1 9}$} \\
\hline ASET & & & & & & \\
\hline Aset Lancar & & & & & & \\
\hline Kas dan setara kas & $1,588,110.00$ & $2,725,891.00$ & $1,595,120.00$ & $2,329,179.00$ & $2,034,169.00$ & $3,571,886.00$ \\
\hline Piutang usaha & $1,532,275.00$ & $1,568,098.00$ & $2,089,949.00$ & $2,229,097.00$ & $1,725,933.00$ & $1,875,909.00$ \\
\hline Persediaan & $34,739,327.00$ & $37,255,928.00$ & $37,545,222.00$ & $37,920,289.00$ & $38,560,045.00$ & $42,847,314.00$ \\
\hline Aset lancar lainnya & $672,888.00$ & $1,018,514.00$ & $702,882.00$ & $1,285,925.00$ & $2,964,572.00$ & $3,786,024.00$ \\
\hline Total Aset Lancar & $38,532,600,000$ & $42,568,431,000$ & $41,933,173,000$ & $43,764,490,000$ & $45,284,719,000$ & $52,081,133,000$ \\
\hline Aset Tidak Lancar & $714,728.00$ & $830,494.00$ & $519,511.00$ & $1,586,865.00$ & $1,053,942.00$ & $1,192,158.00$ \\
\hline TOTAL ASET & $58,220,600.00$ & $63,505,413.00$ & $62,951,634.00$ & $66,759,930.00$ & $69,097,219.00$ & $78,647,274.00$ \\
\hline LIABILITAS DAN EKUITAS & & & & & & \\
\hline Liabilitas Jangka Pendek & $23,783,134.00$ & $24,045,086.00$ & $21,638,565.00$ & $22,611,042.00$ & $22,003,567.00$ & $25,258,727.00$ \\
\hline Liabilitas Jangka Panjang & $1,208,746.00$ & $1,452,418.00$ & $1,748,841.00$ & $1,961,224.00$ & $1,960,367.00$ & $2,457,789.00$ \\
\hline Total Liabilitas & $24,991,880.00$ & $25,497,504.00$ & $23,387,406.00$ & $24,572,266.00$ & $23,963,934.00$ & $27,716,516.00$ \\
\hline Total Ekuitas & $33,228,720.00$ & $38,007,909.00$ & $39,564,228.00$ & $42,187,664.00$ & $45,133,285.00$ & $50,930,758.00$ \\
\hline $\begin{array}{l}\text { TOTAL LIABILITAS DAN } \\
\text { EKUITAS }\end{array}$ & $58,220,600.00$ & $63,505,413.00$ & $62,951,634.00$ & $66,759,930.00$ & $69,097,219.00$ & $78,647,274.00$ \\
\hline
\end{tabular}

Sumber : Laporan Keuangan Tahunan PT Gudang Garam Tbk. (https://www.gudanggaramtbk.com/media/uploads/files/GGRM_AR_2019_FINAL.pdf)

\section{Tinjauan Literatur}

Menurut Ikatan Akuntan Indonesia Indonesia (2009:1) laporan keuangan meliputi bagian dari proses laporan keuangan. Laporan keuangan yang lengkap biasanya meliputi neraca, laporan laba rugi, laporan perubahan ekuitas, laporan perubahan posisi keuangan (yang dapat disajikan dalam berbagai cara misalnya, sebagai laporan arus kas/ laporan arus dana), catatan dan laporan lain serta materi penjelasan yang merupakan bagian integral dari laporan keuangan. Di samping itu termasuk juga skedul dan informasi tambahan yang berkaitan dengan laporan tersebut, misalnya informasi keuangan segmen industri dan geografis serta pengungkapan pengaruh perubahan harga. Sedangkan pendapat lain yaitu menurut Machfoedz dan Mahmudi pengertian laporan keuangan adalah hasil akhir dari proses akuntansi. Proses akuntansi dimulai dari bukti transaksi, kemudian dicatat dalam harian yang disebut jurnal, kemudian secara periodik dari jurnal dikelompokkan ke dalam buku besar sesuai dengan transaksinya, dan tahap terakhir dan proses akuntansi adalah penyusunan laporan keuangan. Selain itu pengertian laporan keuangan menurut Menurut Hutauruk (2017 : 10) tujuan laporan keuangan adalah menyediakan informasi yang menyangkut posisi keuangan, kinerja serta perubahan posisi keuangan suatu entitas yang bermanfaat bagi sejumlah besar pengguna dalam pengambilan keputusan ekonomi. Laporan keuangan yang disusun untuk tujuan ini memenuhi kebutuhan bersama sebagian besar pengguna. 
Namun demikian, laporan keuangan tidak menyediakan semua informasi yang mungkin dibutuhkan pengguna dalam pengambilan keputusan ekonomi karena secara umum menggambarkan pengaruh keuangan dari kejadian di masa lalu, dan tidak diwajibkan untuk menyediakan informasi non keuangan. Menurut Standar Akuntasi Keuangan (Ikatan Akuntan Indonesia 2002:4) tujuan laporan keuangan adalah; 1.Menyediakan informasi yang menyangkut posisi keuangan, kinerja, seta perubahan posisi keuangan suatu perusahaan yang bermanfaat bagi sejumlah besar pemakai dalam pengambilan keputusan ekonomi 2. Laporan keuangan yang disusun untuk tujuan ini memenuhi kebutuhan bersama sebagian besar pemakai. Namun demikian, laporan keuangan tidak menyediakan semua informasi yang mungkin dibutuhkan pemakai dalam pengambilan keputusan ekonomi karena secara umum menggambarkan pengaruh keuangan dan kejadian di masa lalu, 3. Laporan keuangan juga menunjukkan apa yang telah dilakukan manajemen (stewardship) atau pertanggunggjawaban manajemen atas sumber daya yang dipercayakan kepadanya.

\section{Pengertian Analisis Rasio Keuangan}

Analisis Rasio Keuangan adalah analisis kuantitatif yang digunakan untuk mengevaluasi berbagai aspek kinerja operasi dan keuangan perusahaan berdasarkan informasi yang terdapat dalam laporan keuangan perusahaan seperti laporan neraca (balance sheet), laporan aliran kas (cash flow statement) dan laporan laba-rugi (income statement). Rasio Keuangan ini dapat digunakan oleh manajemen perusahaan, kreditur atau pemberi pinjaman serta investor dan para pemegang saham. Rasio Keuangan ini juga digunakan oleh para analisis sekuritas dan lembaga pemeringkat kredit untuk menilai kekuatan dan kelemahan berbagai perusahaan yang akan dianalisisnya.

Menurut Irawati (2005 : 22), Rasio keuangan merupakan teknik analisis dalam bidang manajemen keuangan yang dimanfaatkan sebagai alat ukur kondisi keuangan suatu perusahaan dalam periode tertentu, ataupun hasil-hasil usaha dari suatau perusahaan pada satu periode tertentu dengan jalan membandingkan dua buah variabel yang diambil dari laporan keuangan perusahaan, baik daftar neraca maupun laba rugi.

Sedangkan menurut Kasmir (2012:104), Rasio keuangan merupakan kegiatan membandingkan angka-angka yang ada dalam laporan keuangan dengan cara membagi satu angka dengan angka lainnya. Perbandingan dapat dilakukan antara satu komponen dengan komponen dalam satu laporan keuangan atau antarkomponen yang ad di antara laporan keuangan.

Harvindo, Tahun 2010 memberikan pengertian bahwa rasio merupakan satu angka yang dibedakan dengan angka lainnya sebagai sebuah hubungan. Sementara Jonathan Golin, Tahun 2001 memberikan pernyataan tentang rasio yang merupakan suatu angka yang didefinsikan pada suatu pola kemudian dibandingkan dengan pola lainnya dan dinyatakan oleh persentase.

Sementara itu keuangan merupakan suatu hal yang dihubungkan dengan akuntansi. Seperti melakukan pengelolaan keuangan serta adanya laporan keuangan yang berpengaruh pada analisis rasio keuangan. Jadi analisis rasio keuangan merupakan indeks yang diterapkan dengan adanya angka-angka akuntansi yang saling berhubungan. Kemudian diperoleh berdasarkan pembagian angka yang satu dengan lainnya, begitu menurut James Carter Van Horne mengutip dari Kasmir, tahun 2008.

Manfaat Analisis Rasio Keuangan (Financial Ratio Analysis) 
Analisis Rasio Keuangan memberikan berbagai manfaat bagi manajemen perusahaan, kreditur dan investor. Beberapa manfaat analisis rasio keuangan adalah sebagai berikut :

1. Membantu menganalisis tren kinerja sebuah perusahaan.

2. Membantu para stakeholder untuk membandingkan hasil keuangan suatu perusahaan dengan pesaingnya.

3. Membantu Manajemen, kreditur dan investor untuk mengambil keputusan.

4. Dapat menunjukan letak permasalahan keuangan perusahaan serta kekuatan dan kelemahannya.

Selain itu adapun beberapa kegunaan dari adanya rasio keuangan merupakan hal yang tercipta sebagai berikut ini :

- Perwujudan visualisasi tentang sejarah perusahaan disertai dengan nilai keadaan suatu perusahaan tersebut.

- Perwujudan visualisasi kepada investor serta kreditor tentang kebaikan dan keburukan suatu keadaan atau tempat keuangan perusahaan dari satu periode ke periode lainnya.

- Mampu menetapkan efisiensi kinerja pada manajer perusahaan dengan dituangkan ke dalam catatan keuangan serta laporan keuangan.

- Adanya kemungkinan manajer keuangan melakukan prediksi reaksi dari para calon investor serta kreditor disaat melakukan pencarian guna menambah dana.

- Mampu mewujudkan pembuatan keputasan, ad anya pertimbangan serta melakukan prediksi berdasarkan tren pasar dengan pencapaian perusahaan serta prospek yang akan terjadi nanti di masa datang.

- Standarisasi ukuran penilaian perusahaan agar memudahkan untuk memahami posisi perusahaan yang berada di kalangan industri lainnya.

Kelemahan analisis rasio keuangan menurut Weston dan Brigham (1981: 313) menyatakan rasio keuangan juga memiliki kelemahan yaitu :

1. Banyak perusahaan besar mengoperasikan beberapa divisi yang berbeda pada industri yang berlainan, dan dalam keadaan semacam ini sukar untuk mendapatkan rata-rata industri yang bisa digunakan sebagai bahan pembanding yang tepat.

2. Pembandingan dengan data-data atau standar industri tidak menjamin bahwa prestasi perusahaan telah memuaskan dan beroperasi (dikelola) dengan baik.

3. Pemilihan metode penilaian persediaan dapat memberikan dampak yang besar terhadap tingkat profitabilitas perusahaan dalam periode inflasi

4. Faktor-faktor musiman juga menyebabkan ketimpangan pada analisis rasio

5. Perusahaan dapat menggunakan teknik window dressing agar laporan keuangannya kelihatan lebih baik bagi analisis kredit.

6. Adanya perbedaan sistem akutansi yang digunakan oleh suatu perusahaan dengan perusahaan lain yang menyebabkan penyimpangan tersebut. 
7. Suatu perusahaan yang kuat atau lemah di dalam industrinya belum tentu perusahaan tersebut akan kuat atau lemah dalam industri yang lain.

\section{Jenis-Jenis Rasio Keuangan}

Pada dasarnya angka-angka rasio dapat dikelompokkan menjadi dua golongan, yaitu (Jumingan, 2006: 120):

1) Berdasarkan sumber datanya, yaitu darimana data tersebut diperoleh/dibuat, maka rasio itu dapat dibedakan menjadi tiga antara lain:

- Rasio-rasio neraca, yaitu rasio yang disusun dari data yang berasal dari neraca, misalnya rasio lancar, rasio tunai, rasio modal sendiri dengan total aktiva, rasio tetap dengan utang jangka panjang, dan sebagainya.

- Rasio-rasio laporan laba-rugi, yaitu rasio-rasio yang disusun dari data yang berasal dari laporan laba rugi, misanya rasio laba bruto dengan penjualan netto, rasio laba usaha dengan penjualan netto, opertaing ratio, dan sebagainya.

- Rasio-rasio antarlaporan, yaitu rasio-rasio yang disusun dari data-data yang berasal dari neraca dan aporan labarugi, misalnya rasio penjualan netto dengan aktiva usaha, rasio harga pokok penjualan dengan persediaan rata-rata dan sebagainya.

2) Berdasarkan tujuan penganalisis dalam mengevaluasi suatu perusahaan berdasarkan laporan keuangannya. Menurut Weston dan Brigham (1981: 38), rasio keuangan dapat digolongkan menjadi $\operatorname{tga}$

kategori:

- Rasio likuiditas, bertujuan mengukur kemampuan perusahaan dalam memenuhi kewajiban jangka pendeknya.

- Rasio leverage, bertujuan mengukur sejauhmana kebutuhan keuangan perusahaan dibelanjai dengan dana pinjaman.

- Rasio aktivitas, bertujuan mengukur efektifitas perusahaan dalam mengoperasikan dana.

- Rasio profitabilitas, bertujuan mengukur efektifitas manajemen yang tercermin pada imbalan hasil dari investasi melalui kegiatan penjualan.

- Rasio pertumbuhan, bertujuan mengukur kemampuan perusahaan dalam mempertahankan kedudukannya dalam pertumbuhan perekonomian dan industri.

\section{Rasio Likuiditas}

Menurut Fahmi (2011:121) mengatakan bahwa rasio likuiditas adalah kemampuan suatu perusahaan memenuhi kewajiban jangka pendeknya secara tepat waktu. Contoh membayar listrik, telefon, air PDAM, gaji karyawan, gaji teknisi, gaji lembur, tagihan telepon, dan sebagainya. Karena itu rasio likuiditas sering disebut dengan short term liquidity. Rasio likuiditas secara umum ada 2 (dua) yaitu :

a. Rasio Lancar (Current Ratio) 
Rasio lancar (current ratio) adalah ukuran yang umum digunakan atas solvensi jangka pendek, kemampuan suatu perusahaan memenuhi kebutuhan utang ketika jatuh tempo. Harus dipahami bahwa penggunaan current ratio dalam menganalisis laporan keuangan hanya mampu memberi analisa secara kasar, oleh karena itu perlu adanya dukungan analisa secara kualitatif secara lebih komprehensif. Adapun rumus current ratio adalah : Rasio = Aset lancar/Utang lancar.

b. Rasio Cepat (Quick Ratio)

Quick ratio (acit test ratio) sering disebut dengan istilah rasio cepat adalah ukutan uji solvensi jangka pendek yang lebih teliti daripada rasio lancar karena pembilangnya mengeliminasi persediaan yang dianggap aktiva lancar yang sedikit tidak likuid dan kemungkinan menjadi sumber kerugian. Adapun rumus quick ratio adalah; Quick Ratio = Aset Lancar Persediaan/Utang Lancar

\section{Rasio Solvabilitas (Leverage)}

Menurut Harahap (2011:303) mengatakan bahwa rasio solvabilitasmenggambarkan kemampuan perusahaan dalam membayar kewajiban jangka panjangnya atau kewajiban - kewajibannya apabila perusahaan dilikuidasi. Rasio Solvabilitas terdiri atas :

a. Rasio Utang atas Modal (Debt to Equity Ratio)

Rasio ini menggambarkan sampai sejauh mana modal pemilik dapat menutupi utang - utang kepada pihak luar. Semakin kecil rasio ini semakin baik. Rumusnya adalah : Debt Equity Ratio = Total Hutang / Modal

\section{b. Rasio Pelunasan Utang (Debt Service Ratio)}

Rasio ini menggambarkan sejauhmana laba setelah dikurangi bunga dan penyusutan serta biaya nonkas dapat menutupi kewajiban bunga dan pinjaman. Semakin besar rasio ini semakin besar kemampuan perusahaan menutupi utang - utangnya. Rumusnya adalah : Laba Bersih + Bunga + Penyusutan + Beban Nonkas / Pembayaran Bungan dan Pinjaman

c. Rasio Utang atas Aktiva (Debt to Assets Ratio)

Rasio ini menunjukkan sejauh mana utang dapat ditutupi oleh aktiva. Semakin besar maka perusahaan semakin solvable. Rumusnya adalah : Debt Assets Ratio = Total Hutang / Total Aktiva

Sedangkan Menurut Bringham dan Houston (2010), rasio solvabilitas (leverage) adalah rasio yang digunakan untuk melihat sampai sejauh apa perusahaan menggunakan pendanaan melalui utang (financial leverage). Menurut Kasmir (2010), rasio solvabilitas atau leverage ratio merupakan rasio yang digunakan untuk mengukur sejauh mana aktiva perusahaan dibiayai oleh utang. Artinya seberapa besar beban utang yang ditanggung perusahaan dibandingkan dengan aktivanya. Berdasarkan pengertian tersebut, dapat disimpulkan rasio solvabilitas adalah rasio yang digunakan untuk melihat besarnya aktiva perusahaan yang dibantu oleh hutang. Rasio solvabilitas yang umum digunakan menurut Kasmir (2013) adalah sebagai berikut:

1. Rasio Hutang (Debt Ratio)

Debt ratio merupakan rasio utang yang digunakan untuk mengukur seberapa besar aktiva perusahaan dibiayai oleh utang atau seberapa besar utang perusahaan berpengaruh 
terhadap pengelolaan aktiva. Rata-rata standar industry untuk debt ratio adalah 35\%. Rumus debt ratio yang digunakan adalah:

Debt Ratio = Total Hutang $:$ Total Aktiva $\times 100 \%$

2. Rasio hutang terhadap Ekuitas (Debt to Equity Ratio)

Debt to equity ratio merupakan rasio yang digunakan untuk menilai utang dengan ekuitas. Rasio ini dicari dengan cara membandingkan antara seluruh utang, termasuk utang lancar dengan seluruh ekuitas. Rasio ini berguna untuk mengetahui jumlah dana yang disediakan peminjam (kreditur) dengan pemilik perusahaan. Dengan kata lain rasio ini digunakan untuk mengetahui setiap rupiah modal sendiri yang dijadikan untuk jaminan utang. Rata-rata standar industry untuk debt to equity ratio adalah $80 \%$. Rumus rasio hutang terhadap ekuitas yang digunakan adalah:

Debt to Equity Ratio = Total Hutang : Ekuitas x 100\%

3. Equity Multiplayer

Adalah rasio yang dapat menunjukkan kemampuan perusahaan dalam memanfaatkan ekuitas atau modal yang dimilikinya secara optimal. Rasio ini juga dapat menunjukkan seberapa besar aktiva yang dimiliki perusahaan dibiayai oleh ekuitas atau modal nya. Semakin kecil rasio ini semakin baik bagi perusahaan, karena semakin kecil rasio ini maka semakin besar jumlah modal yang dimiliki perusahaan untuk membiayai aktiva bagi perusahaan. Rumus Equity Multiplayer yang digunakan adalah :

Equity Multiplayer = Total Aktiva : Total Ekuitas

4. Capital Structure

Adalah rasio yang dapat menunjukkan seberapa besar ekuitas atau modal yang dimiliki perusahaan dibiayai atau berasal dari hutang jangka panjang. Semakin besar nilai rasio ini artinya ekuitas atau modal yang dimiliki oleh perusahaan sebagian besar berasal dari pinjaman atau hutang jangka panjang. Apabila perusahaan terlalu banyak memiliki hutang jangka panjang maka akan semakin besar pula beban bunga yang ditanggung oleh perusahaan, karena hutang jangka panjang memiliki presentase bunga yang cukup tinggi. Oleh karena itu, semakin kecil nilai dari rasio ini maka akan semakin baik bagi suatu perusahaan. Rumus capital structure yang digunakan adalah :

Capital Structure = Perbandingan Utang Jangka panjang dengan Ekuitas

\section{Rasio Aktivitas}

Menurut Fahmi (2011 : 132) mengatakan bahwa rasio aktivitas adalah rasio yang menggambarkan sejauh mana suatu perusahaan mempergunakan sumber daya yang dimilikinya guna menunjang aktivitas perusahaan, dimana penggunaan aktivitas ini dilakukan secara sangat maksimal dengan maksud memperoleh hasil yang maksimal. Rasio ini bagi banyak praktisi dan analisis bisnis menyebutnya juga sebagai rasio pengelolaan aset (asset management ratio). Rumus rasio aktivitas secara umum ada 4 (empat) yaitu :

a. Perputaran Persediaan (Inventory Turnover)

Rasio inventory turnover ini melihat sejauh mana tingkat perputaran persediaan yang dimiliki oleh suatu perusahaan. Adapun rumus inventory turnover adalah : Inventory Turnover $=$ Aset Lancar - Persediaan/ Utang Lancar 
b. Rata - Rata Periode Pengumpulan Piutang (Day Sales Outstanding) Rasio Day sales outstanding mengkaji tentang bagaimana suatu perusahaan melihat periode pengumpulan piutang yang akan terlihat. Adapun rumus

Day sales outstanding adalah : Day Sales Outstanding = Piutang / Penjualan Kredi / 360

c. Perputaran Aset Tetap (Fixed Assets Turnover)

Rasio fixed assets turnover disebut juga dengan perputaran aktiva tetap. Rasio ini melihat sejauh mana aktiva tetap yang dimiliki oleh suatu perusahaan memiliki tingkat perputarannya secara efektif dan memberikan dampak pada keuangan perusahaan. Adapun rumus fixed assets turnover adalah $:$ Fixed Assets Turnover $=$ Penjualan $/$ Aktiva Tetap

d. Perputaran Aset (Total Assets Turnover)

Total Assets Turnover disebut juga dengan perputaran total aset. Rasio ini melihat sejauh mana keseluruhan aset yang dimiliki oleh perusahaan terjadi perputaran secara efektif. Adapun rumus total assets turnover adalah : Total Assets Turnover = Penjualan / Jumlah Aktiva

e. Perputaran Aset Jangka Panjang (Long Term Asset Turnover)

Rasio long term asset turnover disebut juga perputaran aset jangka panjang. Adapun rumus dari long term asset turnover adalah : Long Term Asset Turnover = Penjualan / Aktiva Jangka Panjang

\section{Rasio Profitabilitas}

Menurut Munawir (2010), rasio profitabilitas adalah ukuran yang menunjukkan kemampuan perusahaan untuk menghasilkan laba pada periode tertentu. Menurut Harahap (2010:304), rasio profitabilitas menggambarkan kemampuan perusahaan mendapatkan laba melalui semua kemampuan dan sumber yang ada seperti kegiatan penjualan, kas, modal, jumlah karyawan, jumlah cabang dan sebagainya. Sedangkan Sartono (2010) menyatakan profitabilitas yaitu kemampuan perusahaan memperoleh laba dalam hubungannya dengan penjualan, total aktiva maupun modal sendiri.

1. Profit Margin

profit margin merupakan rasio yang digunakan untuk menunjukkan pendapatan bersih perusahaan atas penjualan. Rasio ini merupakan ukuran keuntungan dengan membandingkan antara laba setelah bunga dan pajak dibandingkan dengan penjualan. Rata-rata standar industri untuk net profit margin yaitu $20 \%$. Rumus yang digunakan yaitu :

Profit margin = Laba Setelah Bunga dan Pajak : Penjualan x 100\%

2. Return On Asset

Return On Asset adalah rasio yang dapat menunjukkan seberapa besar keuntungan yang dapat diperoleh perusahaan dari aset yang dimiliki perusahaan, atau dapat juga dikatakan bahwa rasio ini dapat menunjukkan seberapa efektif dan efisiennya perusahaan dalam mengelola aset yang dimilikinya sehingga dapat memperoleh laba yang lebih tinggi dengan aset tersebut. Rumus Return On Asset yang digunakan adalah :

Return On Asset = Laba Setelah Bunga dan Pajak : Total Aktiva x 100\%

3. Hasil Pengembalian Ekuitas (Return On Equity) 
Return on equity atau rentabilitas modal sendiri merupakan rasio untuk mengukur laba bersih sesudah pajak dengan modal sendiri. Rasio ini menunjukkan efisiensi penggunaan modal sendiri. Semakin tinggi rasio ini, maka akan semakin baik. Artinya, posisi pemilik perusahaan semakin kuat, demikian pula sebaliknya. Rata-rata standar industry untuk return on equity adalah $40 \%$. Rumus yang digunakan yaitu:

$\mathrm{ROE}=$ Laba Setelah Bunga dan Pajak : Total Ekuitas x 100\%

\section{Analisis Du Pont}

Dalam melakukan analisis tersebut, ada banyak jenis analisis yang dapat digunakan. Salah satu analisis tersebut adalah Dupont Analysis. Dupont Analysis adalah rasio keuangan yang digunakan untuk menganalisis kemamuan perusahaan untuk meningkatkan pengembalian atas ekuitas, atau Return on Equity (ROE). Sejatinya, Dupont Analysis merupakan alat analisis yang digunakan untuk menganalisis laba dari perusahaan atau bisnis.

Dupont Analysis merupakan metode analisis yang dicetuskan oleh DuPont Corporation. Pengembangan metode Dupont Analysis dilaksanakan pada tahun 1920 oleh perusahaan tersebut. Dupont Analysis dinilai berguna untuk menghindari kesimpulan yang menyesatkan dalam hal analisis keuntungan perusahaan.

Perhitungan Dupont Analysis mempunya satu dasar indikator yang fundamental, yaitu Return on Equity (ROE). Pada indikator ROE sendiri, ada tiga indikator keuangan yang mempengaruhinya. Indikator-indikator tersebut adalah efisiensi operasi, efisiensi penggunaan aset, dan leverage keuangan. Efisiensi operasi diwakili oleh margin laba bersih atau laba bersih dibagi dengan total penjualan atau pendapatan, efisiensi penggunaan aset diukur dengan rasio perputaran aset, sedangkan leverage diukur dengan pengganda ekuitas. Sebagaimana Dupont Analysis berhubungan erat dengan ROE, maka Dupont Analysis juga berhubungan erat dengan ketiga indikator utama pada ROE. Indikator-indikator tersebut adalah:

\section{Net Profit Margin (Marjin Laba Bersih)}

Rasio margin laba, juga disebut rasio laba atas penjualan atau rasio laba kotor, adalah rasio profitabilitas yang mengukur jumlah laba bersih yang diperoleh dengan setiap nilai penjualan yang dihasilkan dengan membandingkan laba bersih dan penjualan bersih suatu perusahaan. Dengan kata lain, rasio margin laba menunjukkan persentase penjualan yang tersisa setelah semua biaya dibayar oleh bisnis. Kreditor dan investor menggunakan rasio ini untuk mengukur seberapa efektif suatu perusahaan dapat mengubah penjualan menjadi laba bersih. Investor ingin memastikan laba cukup tinggi untuk membagikan dividen, sementara kreditor ingin memastikan perusahaan memiliki cukup laba untuk membayar kembali pinjamannya. Dengan kata lain, pihak-pihak luar ingin tahu efisiensi dari perusahaan.

\section{Total Asset Turnover (Total Perputaran Aset)}

Rasio perputaran aset adalah rasio efisiensi yang mengukur kemampuan perusahaan untuk menghasilkan penjualan dari asetnya dengan membandingkan penjualan bersih dengan rata-rata 
total aset. Dengan kata lain, rasio ini menunjukkan seberapa efisien suatu perusahaan dapat menggunakan asetnya untuk menghasilkan penjualan.Rasio perputaran total aset menghitung penjualan bersih sebagai persentase aset untuk menunjukkan berapa banyak penjualan yang dihasilkan dari setiap nilai aset perusahaan. Misalnya, rasio 0,5 berarti bahwa setiap 1 rupiah aset menghasilkan 0,5 rupiah penjualan.

\section{Financial Leverage (Leverage Keuangan)}

Rasio leverage keuangan, yang umumnya disebut rasio ekuitas atau utang, adalah rasio yang mengukur nilai ekuitas dalam suatu perusahaan dengan menganalisis gambaran utangnya secara keseluruhan. Rasio ini digunakan untuk membandingkan utang atau ekuitas dengan aset serta saham yang beredar untuk mengukur nilai sebenarnya dari ekuitas dalam bisnis.

Atas dasar itu, rasio leverage keuangan berguna untuk mengukur beban utang perusahaan secara keseluruhan dan membandingkannya dengan aset atau ekuitas. Rasio ini menunjukkan seberapa banyak aset perusahaan milik pemegang saham daripada kreditor. Ketika pemegang saham memiliki sebagian besar aset, perusahaan dikatakan memiliki leverage rendah. Ketika kreditor memiliki mayoritas aset, perusahaan dianggap memiliki leverage tinggi. Semua pengukuran ini penting bagi investor untuk memahami seberapa berisiko struktur modal suatu perusahaan dan jika perlu berinvestasi. Sejatinya, Dupont Analysis memang didasarkan pada perhitungan ROE, dimana perhitungan ROE dirumuskan sebagai berikut:

ROE $=$ Proft Margin $\times$ Total Asset Turnover $\times$ Financial Leverage

Untuk lebih rincinya, rumus ROE ditulis sebagai:

$R O E=($ NetIncome/NetSales $) \times($ NetSales/AverageTotalAssets $) \times($ Total Assets/Total Equity)

Sebenarnya, nilai ROE dapat dirumuskan sebagai

$R O E=$ Laba bersih / Ekuitas pemegang saham

Namun dalam Dupont Analysis, rumus tersebut diperluas. Perluasan rumus tersebut berguna untuk analisis di tiap komponen penghasil laba pada perusahaan.

\section{Analisis DuPont $=$ Net Profit Margin x Asset Turnover x Equity Multiplier}

Sehingga dapat disimpulkan Dupont Analysis merupakan suatu analisis yang digunakan untuk mengevaluasi indikator-indikator utama dari ROE beserta ROE-nya. Hal ini membuat investor mengetahui kegiatan keuangan apa yang paling berkontribusi terhadap perubahan ROE pada perusahan tersebut. Atas dasar itu, seorang investor menjadi dapat membandingan efisiensi 
operasional dari dua perusahaan. Selain berguna untuk investor, Dupont Analysis juga berguna untuk seorang manajer perusahaan. Perhitungan Dupont Analysis yang merinci berbagai komponen keuangan yang mempengaruhi kinerja perusahaan dalam memperoleh laba membuat manajer mengetahui kekuatan dan kelemahan dari indikator komponen keuangan perusahaan. Hal ini dapat digunakan manajer untuk mengambil kebijakan dalam mengelola perusahaannya agar operasinya ebih efisien.

\section{METODE PENELITIAN}

\section{Jenis dan Sumber Data}

Pengertian Metode penelitian adalah langkah yang dimiliki dan dilakukan oleh peneliti dalam rangka untuk mengumpulkan informasi atau data serta melakukan investigasi pada data yang telah didapatkan tersebut. Metode penelitian memberikan gambaran rancangan penelitian yang meliputi antara lain: prosedur dan langkah-langkah yang harus ditempuh, waktu penelitian, sumber data, dan dengan langkah apa data-data tersebut diperoleh dan selanjutnya diolah dan dianalisis.

\section{Jenis Data}

a. Data Kualitatif

Data kualitatif adalah data yang disajikan dalam bentuk kata-kata (tulisan), gambar (audio) atau video yang memiliki makna. Data-data tersebut diperoleh dari wawancara, pengamatan, pemotretan, perekaman dan lain-lain. Pada intinya data kualitatif adalah data yang bukan merupakan bilangan angka sehinga tidak dianalisis dengan ilmu statistik (statistika).

\section{b. Data Kuantitatif}

Menurut Sugiyono (2011), data kuantitatif adalah data yang berbentuk angka atau data kualitatif yang diangkakan. Data kuantitatif yang digunakan dalam makalah ini adalah laporan keuangan perusahaan dari tahun 2014-2019. Datat tersebut untuk mengetahui jumlah atau besaran dari analisis Rasio Keuangan dalam komparatif laporan keuangan PT. Gudang Garam Tbk.

\section{Sumber Data}

Sumber data yang digunakan dalam penelitian ini adalah data sekunder. Menurut Sugiyono (2014), sumber data sekunder merupakan sumber yang tidak langsung memberikan data kepada pengumpul data, misalnya lewat orang lain atau dokumen. Dalam penelitian ini, data sekunder diperoleh melalui internet, buku-buku, jurnal dan tesis yang berhubungan dengan penelitian ini.

\section{Metode Pengumpulan data}

Adapun metode pengumpulan data yang digunakan yaitu :

1. Penelitian kepustakaan adalah suatu studi yang digunakan dalam mengumpulkan informasi dan data dengan bantuan berbagai macam material yang ada di perpustakaan seperti dokumen, buku, majalah, kisah-kisah sejarah, dsb (Mardalis: 1999). Penelitian kepustakaan dalam penelitian ini berupa buku-buku, jurnal dan tesis yang berhubungan dengan penelitian ini

2. Dokumen yaitu catatan peristiwa yang sudah berlalu dan berbentuk tulisan, gambar, atau karya-karya monumental dari seseorang (Sugiyono, 2014). Data yang digunakan dalam dokumen 
ini berupa gambaran umum PT. Gudang Garam Tbk. Yang diperoleh melalui situs www.gudanggaramtbk.com dan data laporan keuangan perusahaan dari tahun 2014- 2019 yang diperoleh dari Bursa Efek Indonesia yang diunduh melalui situs https://www.gudanggaramtbk.com/media/uploads/files/GGRM_AR_2019_FINAL.pdf

\section{Metode Analisis Data}

Du pont system merupakan bagan yang dirancang untuk menunjukkan pengembalian atas aset yang diperoleh dari perkalian marjin laba dengan total perputaran total aset. Tujuan penelitian ini adalah: Untuk mengetahui gambaran kinerja keuangan dengan menggunakan metode du pont system dan untuk mengetahui faktor-faktor yang menyebabkan penurunan kinerja keuangan dengan menggunakan analisis $d u$ pont system pada PT Gudang Garam Tbk, yang Terdaftar di Bursa Efek Indonesia.

Metode analisis data yang digunakan dalam penelitian ini adalah analisis statistic deskriptif dan analisis $d u$ pont. Menurut Sugiyono (2014), penelitian statistic deskriptif yaitu analisis data dengan cara mendeskripsikan atau menggambarkan data yang telah terkumpul sebagaimana adanya tanpa bermaksud membuat kesimpulan yang berlaku untuk umum. Menurut sawir (2005) analisis du pont yang menggabungkan rasio-rasio aktivitas dan margin keuntungan atas penjualan untuk menunjukkan bagaimana rasio-rasio tersebut berinteraksi untuk menentukan profitabilitas aktiva-aktiva yang dimiliki perusahaan.

Tabel 2 Analsis Ratio Keuangan

\begin{tabular}{|r|r|r|r|r|r|r|r|}
\hline \multicolumn{1}{|c|}{ Tahun } & Penjualan & $\begin{array}{c}\text { HPP (- } \\
\text { ) }\end{array}$ & EBIT & $\begin{array}{c}\text { Biaya } \\
\text { Bunga } \\
(-)\end{array}$ & EBT & PPH & $\begin{array}{l}\text { Laba Th } \\
\text { Berjalan }\end{array}$ \\
\hline 2014 & 65,185 & 51,806 & 13,379 & 6,173 & 7,205 & $-1,810$ & 5,395 \\
\hline 2015 & 70,365 & 54,879 & 15,485 & 6,850 & 8,635 & $-2,182$ & 6,452 \\
\hline 2016 & 76,274 & 59,657 & 16,616 & 7,685 & 8,931 & $-2,258$ & 6,672 \\
\hline 2017 & 83,305 & 65,084 & 18,221 & 8,165 & 10,436 & $-2,681$ & 7,755 \\
\hline 2018 & 95,707 & 77,063 & 18,644 & 8,165 & 10,479 & $-2,686$ & 7,793 \\
\hline 2019 & 110,523 & 87,740 & 22,783 & 8,295 & 14,487 & $-3,607$ & 10,880 \\
\hline
\end{tabular}

Sumber: Laporan Keuangan Tahunan PT Gudang Garam Tbk. (https://www.gudanggaramtbk.com/media/uploads/files/GGRM_AR_2019_FINAL.pdf) 


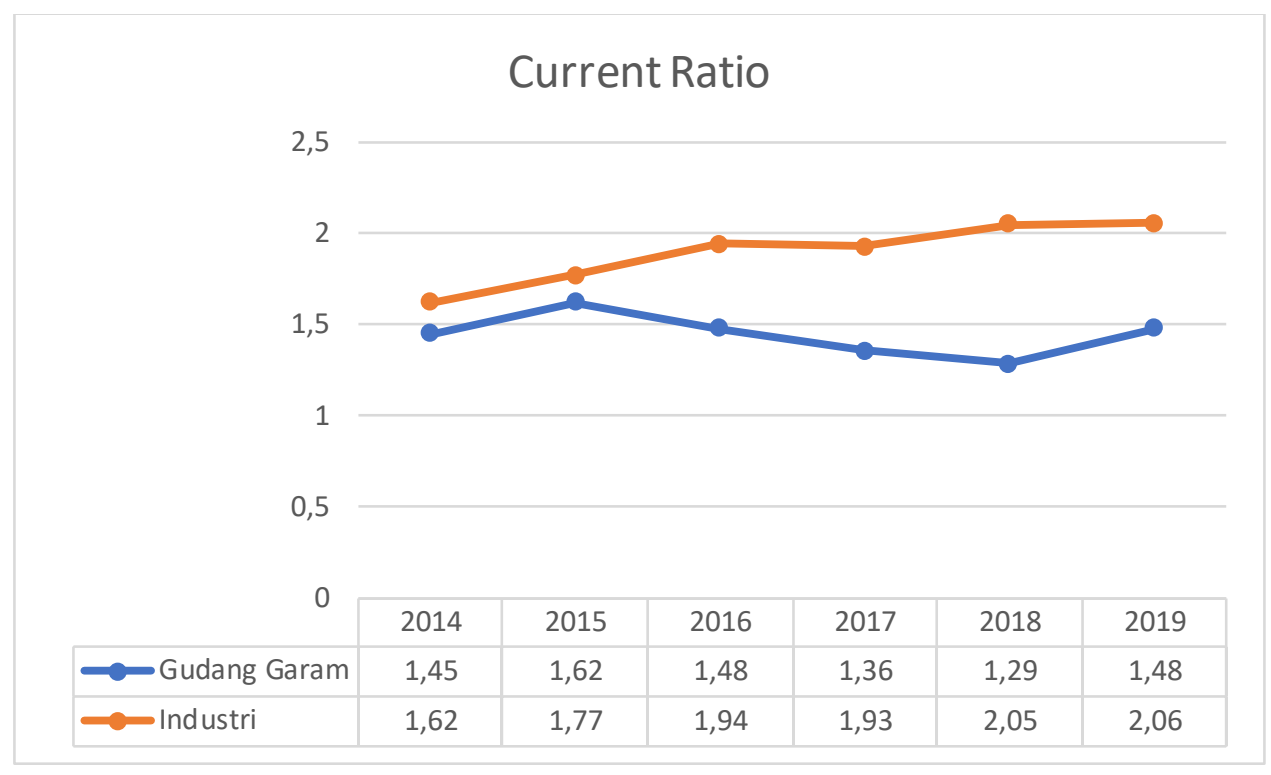

\section{Grafik 1. Perbandingan Current Ratio Gudang Garam dan industrinya}

Current Ratio di atas menunjukan angka - angka yang > 1. Hal ini menunjukan bahwa aktiva lancar > Utang Lancar, maka PT. Gudang Garam Tbk. \& Total Industri Tobacco dianggap efisien dalam tingkat likuiditas dan mampu memenuhi kewajiban jangka pendeknya. Jika kita amati grafik perbandingan current ratio antara kemampuan PT. Gudang Garam Tbk \& Total Industri Tobacco diatas, penulis melakukan rata-rata perhitungan Current Ratio pada PT. Gudang Garam Tbk selama enam tahun dan membandingkan dengan rata-rata perhitungan.

Sesuai dengan grafik diatas dapat disimpulkan bahwa total Current Ratio PT Gudang Garam Tbk perbandingan dengan Total Industri Tobacco menunjukkan angka perbandingan yang berbeda-beda dari tahun ke tahun. Oleh karena itu untuk hasil yang lebih akurat akan dilakukan rata-rata nilai Total Current Ratio selama enam tahun. Dimana hasil rata-rata nilai Total Current Ratio PT Gudang Garam Tbk. sebesar 1,07 sedangkan total industri Tobacco sebesar 1,09. Olehkarena itu dapat disimpulkan bahwa nilai total Current Ratio PT Gudang Garam Tbk berada pada posisi lebih rendah di bandingkan dengan Total Industri Tobacco. Sehingga Total Industri Tobacco lebih baik di bandingkan PT Gudang Garam Tbk. 


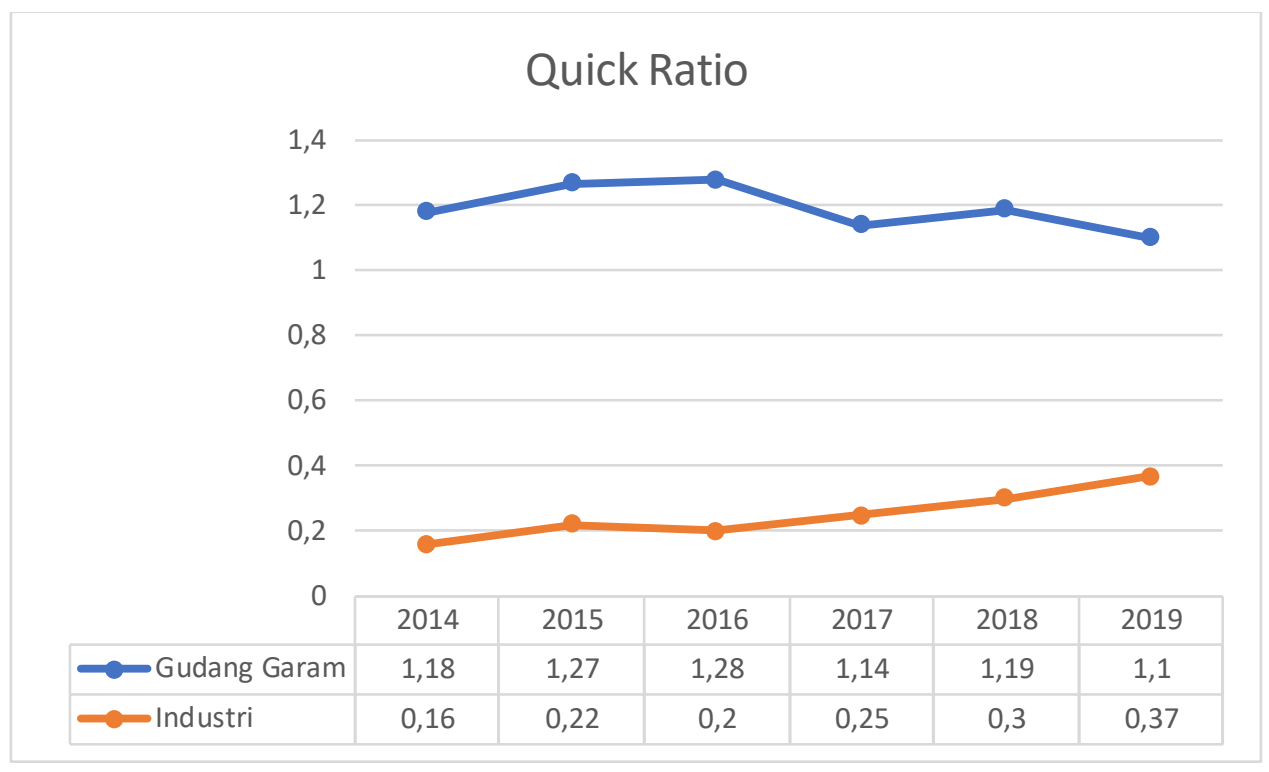

Grafik 2 Perbandingan Quick Ratio Gudang Garam dan Industrinya

Perhitungan Quick Ratio dilakukan dengan membagi "Aktiva Lancar (Current Asset" setalah dikurangi "Persediaan (Inventory)" dengan "Utang Lancar (Current Liabilities)".

Perhitungan Quick Ratio dilakukan dengan membagi "Aktiva Lancar (Current Asset" setalah dikurangi "Persediaan (Inventory)" dengan "Utang Lancar (Current Liabilities)".

Quick Ratio menggambarkan tingkat likuiditas karena Quick Ratio = Aktiva Lancar Persediaan. Quick Ratio menunjukan akan lebih baik jika menghasilkan $>1$.

Sesuai dengan grafik diatas dapat disimpulkan bahwa Total Quick Ratio PT Gudang Garam Tbk perbandingan dengan Total Industri Tobacco menunjukkan angka perbandingan yang berbedabeda dari tahun ke tahun. Oleh karena itu untuk hasil yang lebih akurat akan dilakukan rata-rata nilai Quick Ratio selama enam tahun. Dimana hasil rata-rata nilai Total Quick Ratio PT Gudang Garam Tbk, sebesar 1,25 sedangkan total industri Tobacco sebesar 0,39. Olehkarena itu dapat disimpulkan bahwa nilai total Quick Ratio PT Gudang Garam Tbk berada pada posisi lebih tinggi di bandingkan dengan Total Industri Tobacco. Sehingga Total Industri Tobacco lebih baik di bandingkan PT Gudang Garam Tbk. 


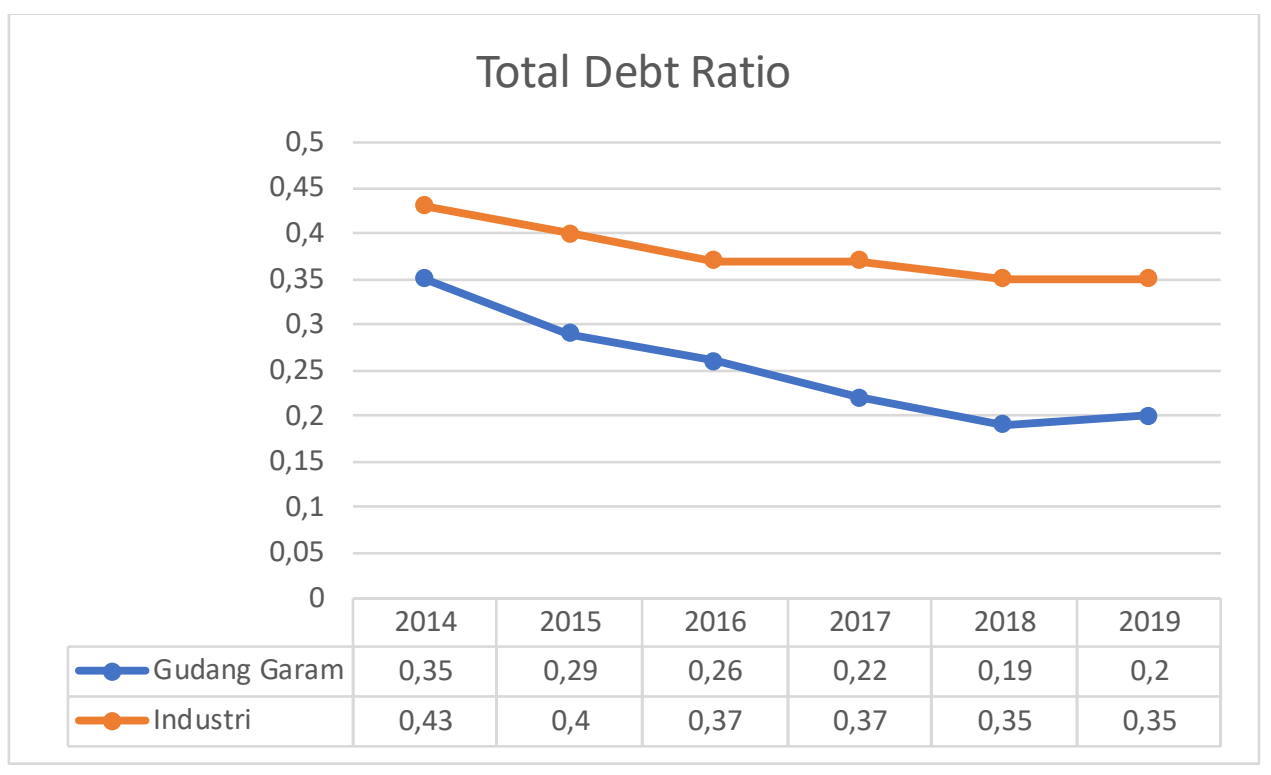

\section{Grafik 3 Perbandingan Total Debt Ratio Gudang Garam dan Industrinya}

Total debt ratio dapat menunjukkan seberapa besar aktiva yang dimiliki oleh perusahaan dibiayai oleh hutang. Semakin besar nilai rasio ini artinya aktiva yang dimiliki oleh perusahaan dibiayai atau dibeli dengan menggunakan hutang. Sehingga semakin besar nilai rasio ini maka semakin besar pula risiko bagi para kreditur atau pihak yang memberikan pinjaman kepada perusahaan.

Sesuai dengan grafik diatas dapat disimpulkan bahwa Total debt ratio PT Gudang Garam Tbk perbandingan dengan Total Industri Tobacco menunjukkan angka perbandingan yang berbedabeda dari tahun ke tahun. Oleh karena itu untuk hasil yang lebih akurat akan dilakukan rata-rata nilai Total debt ratio selama enam tahun. Dimana hasil rata-rata nilai Total debt ratio PT Gudang Garam Tbk. sebesar 0,25 sedangkan total industri Tobacco sebesar 0,36. Olehkarena itu dapat disimpulkan bahwa nilai total debt ratio PT Gudang Garam Tbk berada pada posisi lebih rendah di bandingkan dengan Total Industri Tobacco. Sehingga Total Industri Tobacco lebih baik di bandingkan PT Gudang Garam Tbk. 


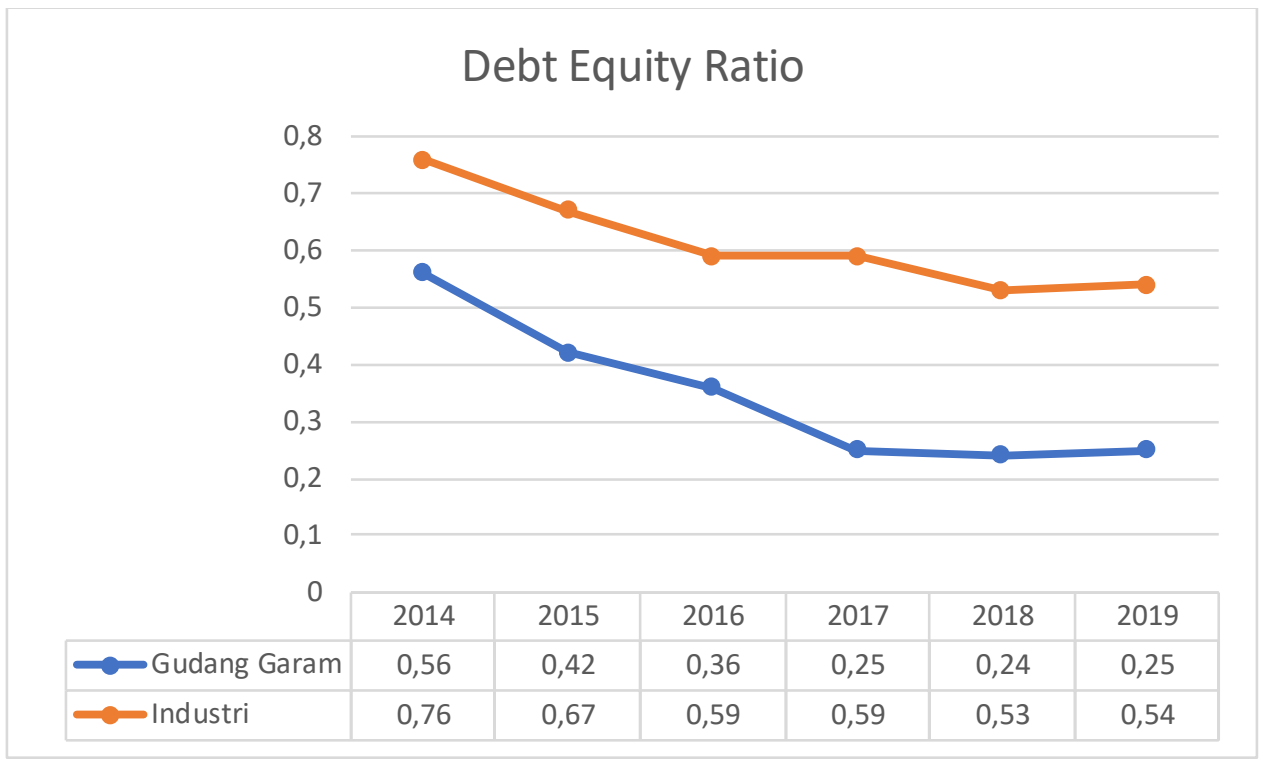

\section{Grafik 4 Perbandingan Total Debt Ratio Gudang Garam dan Industrinya}

Analisis ini menunjukan pengurangan dari "Total Aset" dikurangi "Total Ekuitas" kemudian dibagi dengan "Total Aset". Rasio ini mengukur seberapa besar aktiva perusahaan dibiayai oleh utang atau seberapa besar hutang perusahaan berpengaruh terhadap pengelolaan aktiva.

Sesuai dengan gambar grafik diatas maka jika dibandingkan dari rata-rata perhitungan Total Debt Ratio pada PT. Gudang Garam Tbk selama enam tahun dengan rata-rata perhitungan Total Debt Ratio pada Total Industri Tobacco selama enam tahun, adalah dimana PT. Gudang Garam lebih tinggi dari pada Total Industri Tobacco. Dimana hasil rata-rata nilai Total debt ratio PT Gudang Garam Tbk. sebesar 0,23 sedangkan total industri Tobacco sebesar 0,59. Hal tersebut ditunjukkan karena adanya tingkat resiko utang oleh aset pada Industri lebih kecil dari pada PT. Gudang Garam Tbk maka dapat disimpulkan bahwa Total Industri Tobacco lebih baik dari PT. Gudang Garam Tbk. 


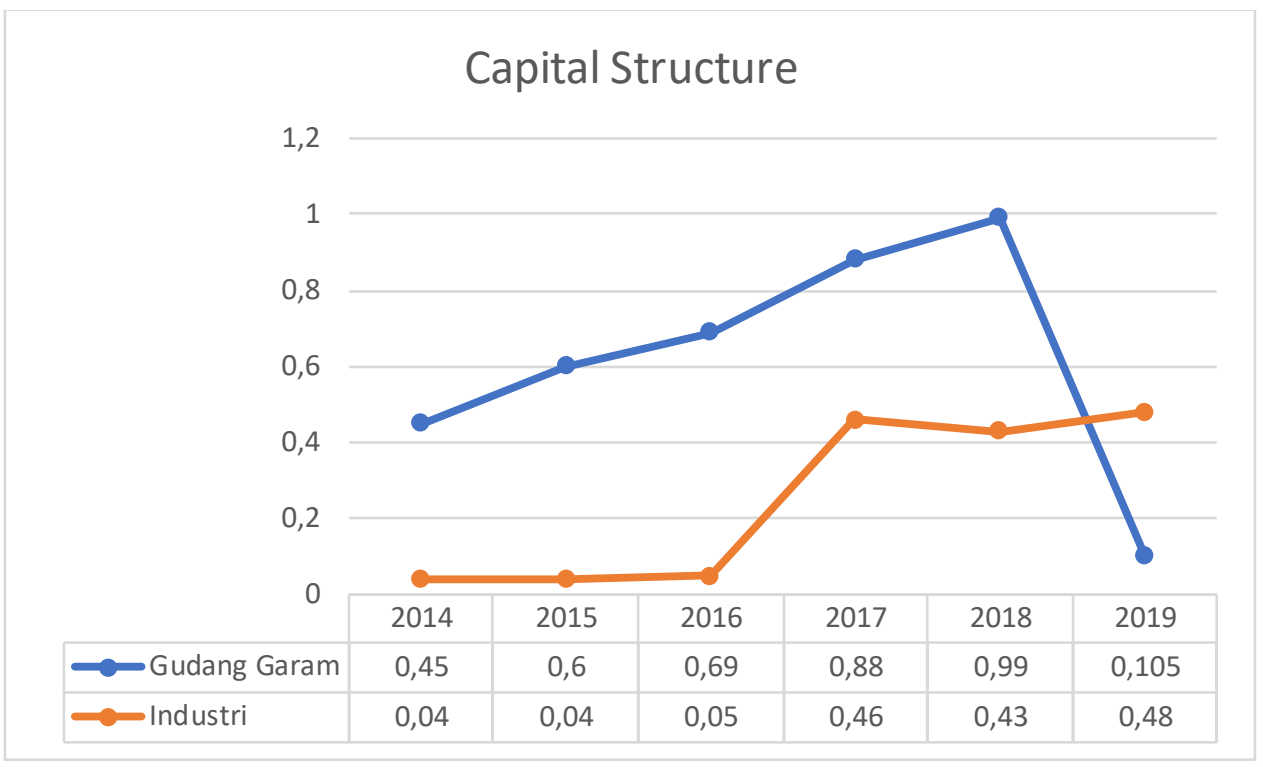

\section{Grafik 5 Perbandingan Capital Structure Gudang Garam dan Industrinya}

Capital Structure dapat digunakan untuk mengetahui jumlah utang dan atau ekuitas yang digunakan oleh perusahaan untuk membiayai aktivitas operasional dan pembelian aset perusahaan. Struktur ini biasanya dinyatakan atau direpresentasikan oleh rasio utang terhadap ekuitas (debt-to-equity ratio). Dengan kata lain, struktur modal digunakan sebagai alat keputusan manajemen dalam mempertimbangkan dan menentukan pendanaan jangka panjang perusahaan.

Maka jika dilihat dari gambar grafik diatas dimana capital structure PT Gudang Garam Tbk. Dibandingkan dengan Total Industri Tobacco berbeda-beda setiap tahunnya. Maka untuk mengetahui hasil yang lebih akurat dapat dilakukan rata-rata dengan mencari nilai capital structure selama enam tahun. Untuk hasli rata-rata nilai capital structure PT Gudang Garam Tbk. sebesar 0,45 sedangkan Total Industri Tobacco sebesar 0,65. Sehingga dapat disimpulkan bahwa nilai capital structure PT Gudang Garam Tbk. berada pada posisi lebih rendah di bandingkan dengan total industri Total Industri Tobacco. Olehkareena itu jika disimpulkan PT Gudang Garam Tbk lebih baik di bandingkan Total Industri Tobacco. 


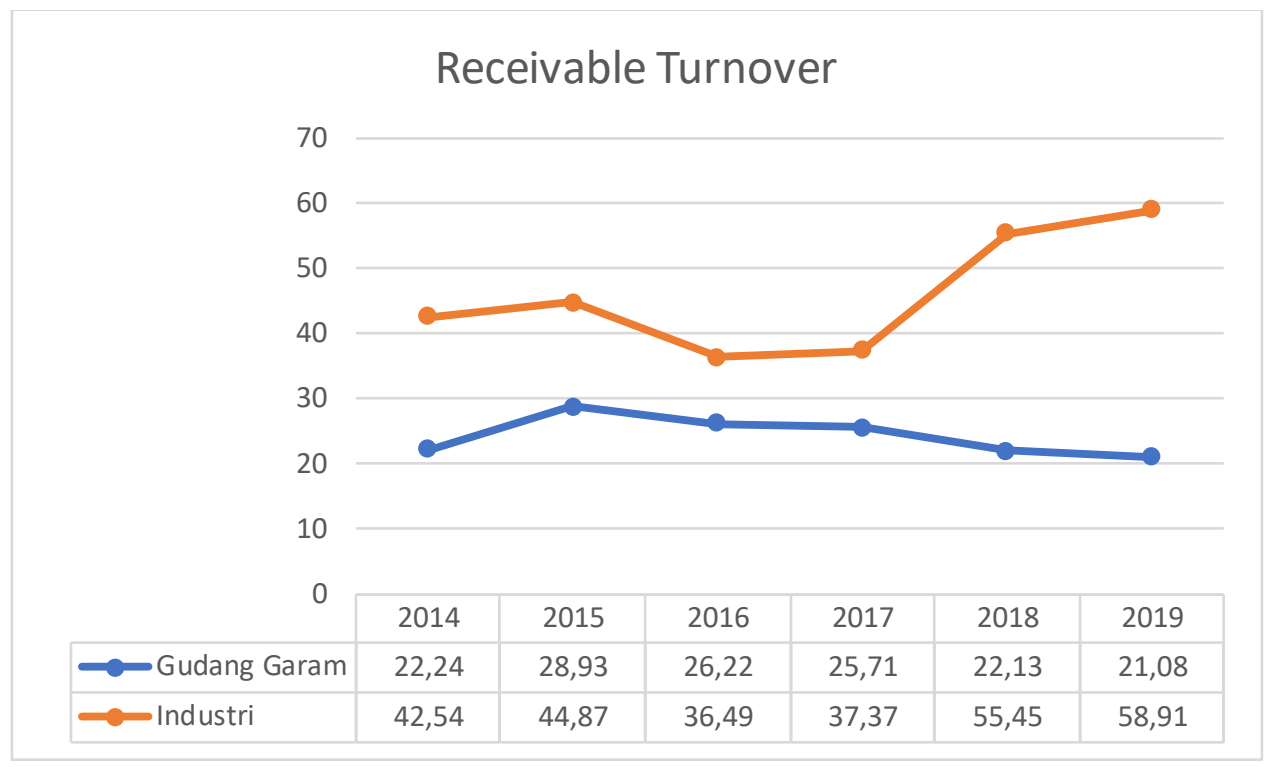

\section{Grafik 6 Perbandingan Receivable Turnover Gudang Garam dan Industrinya}

Receivable turnover dapat digunakan untuk mengetahui perputaran Piutang (Receivable Turnover) maka akan dapat diketahui bagaimana kinerja bagian marketing dalam mencari pelanggan yang potensial membeli akan tetapi juga potensial membayar piutangnya. Selain itu dapat menunjukkan berapa kali piutang dapat berputar dalam setahun. Semakin tinggi nilai receivable turnover pada perusahaan maka piutang yang dapat ditagih oleh perusahaan semakin tinggi oleh perusahaan sehingga memperkecil kemungkinan piutang tidak tertagih dan baik juga bagi arus kas perusahaan.

Jika dilihat dari gambar grafik diatas dimana receivable turnover PT Gudang Garam Tbk, dibandingkan dengan Total Industri Tobacco berbeda-beda setiap tahun. Oleh karena itu untuk mendapatkan hasil yang lebih akurat dapat dilakukan mnejumlahkan nilai rata-rata receivable turnover selama enam tahun. Hasil rata-rata nilai receivable turnover PT Gudang Garam Tbk. sebesar 2,95 Total Industri Tobacco sebesar 3,89. Maka dapat disimpulkan bahwa nilai receivable turnover PT Gudang Garam Tbk. berada pada posisi lebih rendah di bandingkan dengan Total Industri Tobacco. Oleh karena itu PT Gudang Garam Tbk. lebih baik di bandingkan Total Industri Tobacco. 




\section{Grafik 7 Perbandingan Day's Sale In Receivable Gudang Garam dan Industrinya}

Day's sale in receivable dapat menunjukkan berapa lama rata-rata waktu yang dibutuhkan perusahaan untuk menagih setiap piutang yang tertagih. Semakin kecil nilai day's sale in receivable semakin cepat piutang dilunasi.

Sesuai dengan grafik diatas maka day's sale in receivable PT Gudang Garam Tbk. perbandingan dengan Total Industri Tobacco berbeda-beda setiap tahun. Sehingga untuk mengetahui hasil yang lebih akurat apat dilakukan dengan men jumlahkan nilai rata-rata day's sale in receivable selama enam tahun. Hasil rata-rata nilai day's sale in receivable PT Gudang Garam Tbk. sebesar 220 hari sedangkan Total Industri Tobacco sebesar 249 hari. Oleh karena itu dapat disimpulkan bahwa nilai day's sale in receivable PT Gudang Garam Tbk lebih rendah di bandingkan dengan Total Industri Tobacco. Maka dapat disimpulkan dimana PT Gudang Garam Tbk. lebih baik di bandingkan Total Industri Tobacco.

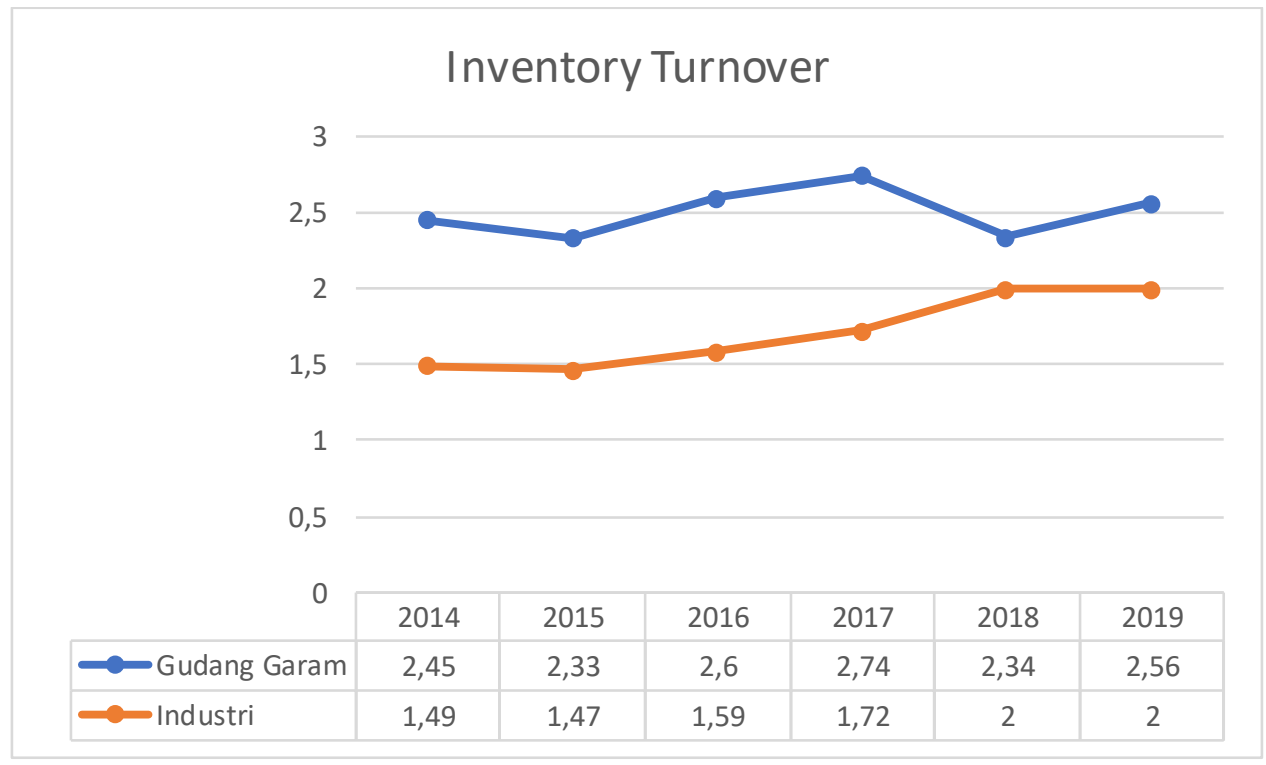




\section{Grafik 8 Perbandingan Inventory Turnover Gudang Garam dan Industrinya}

Inventory turnover digunakan untuk mengetahui sebuah rasio efisiensi yang menunjukkan seberapa efektif dari persediaan yang dapat dikelola dengan membandingkan harga pokok penjualan (HPP) dalam persediaan rata-rata untuk suatu periode atau dapat menunjukkan berapa kali persediaan dapat berputar dalam satu tahun atau dapat juga dikatakan rasio ini menunjukkan tingkat efisiensi dan efektifitas dari persediaan. Semakin tinggi nilai inventory turnover menunjukkan perusahaan menjual persediaan secara maksimal.

Sesuai dengan gambar grafik diatas maka inventory turnover PT Gudang Garam Tbk, dibandingkan dengan Total Industri Tobacco setiap tahun. Sehingga untuk mengetahui hasil yang lebih akurat dapat dilakukan dengan menjumlahkan nilai rata-rata inventory turnover selama enam tahun. Untuk hasil rata-rata nilai inventory turnover PT Gudang Garam Tbk. sebesar 2.78 sedangkan Total Industri Tobacco sebesar 1.7. Maka dapat disimpulkan bahwa nilai inventory turnover PT Gudang Garam Tbk. berada pada posisi lebih tinggi di bandingkan dengan Total Industri Tobacco. Sehingga dapat disimpulkan bahwa Industri Tobacco lebih baik di bandingkan total PT Gudang Garam Tbk.

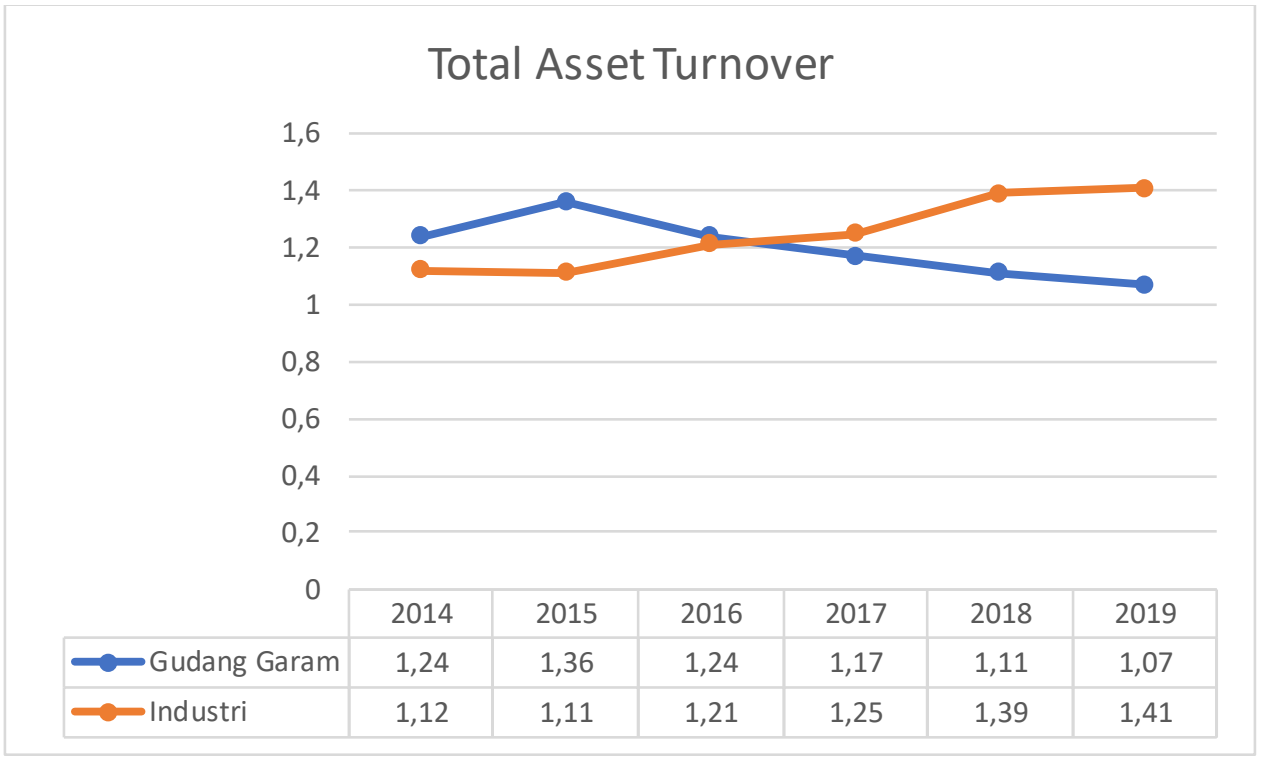

\section{Grafik 9 Perbandingan Total Asset Turnover Gudang Garam dan Industrinya}

Total asset turnover dimana perhitungan keuangan perusahaan, akan mengenal istilah Rasio Perputaran Total Aset (Total Asset Turnover Ratio) yang merupakan rasio aktivitas berguna untuk mengukur seberapa kemampuan perusahaan dalam menghasilkan penjualan dari jumlah aset yang dimiliki

Sesuai dengan gambar grafik diatas diamana total asset turnover PT Gudang garam Tbk, dibandingkan dengan Total Industri Tobacco berbeda-beda setiap tahun. Sehingga untuk hasil yang lebih akurat dapat dilakukan dengan menjumlahkan nilai rata-rata total asset turnover selama enam tahun. Untuk hasil rata-rata nilai total asset turnover PT Gudang Garam Tbk, sebesar 1.09 sedangkan Total Industri Tobacco sebesar 1.13. Maka dapat disimpulkan dimana nilai total asset turnover PT Gudang Garam Tbk. berada pada posisi lebih rendah di bandingkan 
dengan Total Industri Tobacco. Sehingga dapat disimpulkan bahwa PT Gudang Garam Tbk lebih baik di bandingkan Total Industri Tobacco.

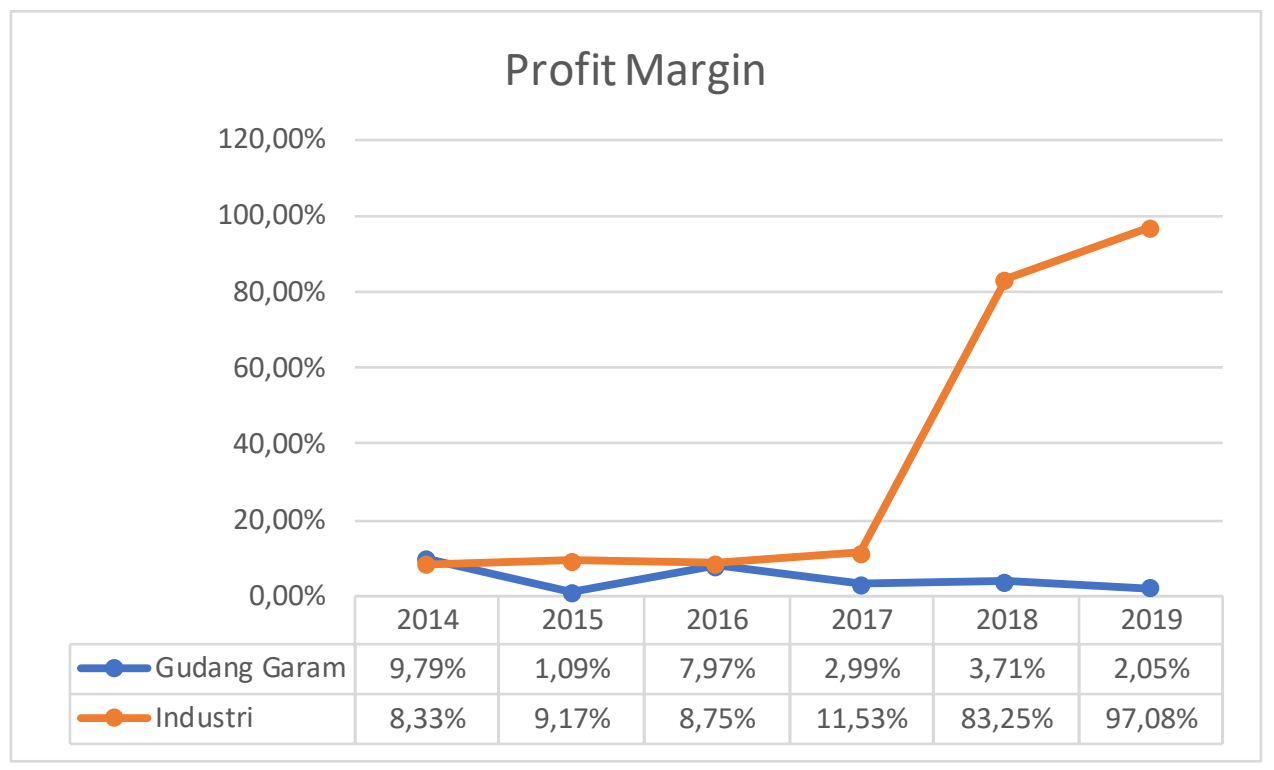

Grafik 10 Perbandingan Profit Margin Gudang Garam dan Industrinya

Profit margin digunakan untuk mengetahui selisih antara nilai penjualan setelah dikurangi semua biaya operasi dibagi jumlah penjualan; perhitungan laba sebagai perbandingan terhadap penjualan bersih dan modal perusahaan (profit margin)

Sesuai dengan gambar grafik diatas dimana profit margin PT Gudang Garam Tbk, dibandingkan dengan Total Industri Tobacco berbeda-beda setiap tahun. Maka untuk memperoleh hasil yang lebih akurat dapat dilakukan dengan menjumlahkan nilai rata-rata profit margin selama enam tahun. Untuk hasil rata-rata nilai profit margin PT Gudang Garam Tbk. sebesar 1,12\% sedangkan Total Industri Tobacco sebesar 1.19\%. Maka dapat disimpulkan dimana nilai profit margin PT Gudang Garam Tbk. berada pada posisi lebih rendah di bandingkan dengan Total Industri Tobacco. Sehingga dapat disimpulkan bahwa PT Gudang Garam Tbk lebih baik di bandingkan Total Industri Tobacco. 


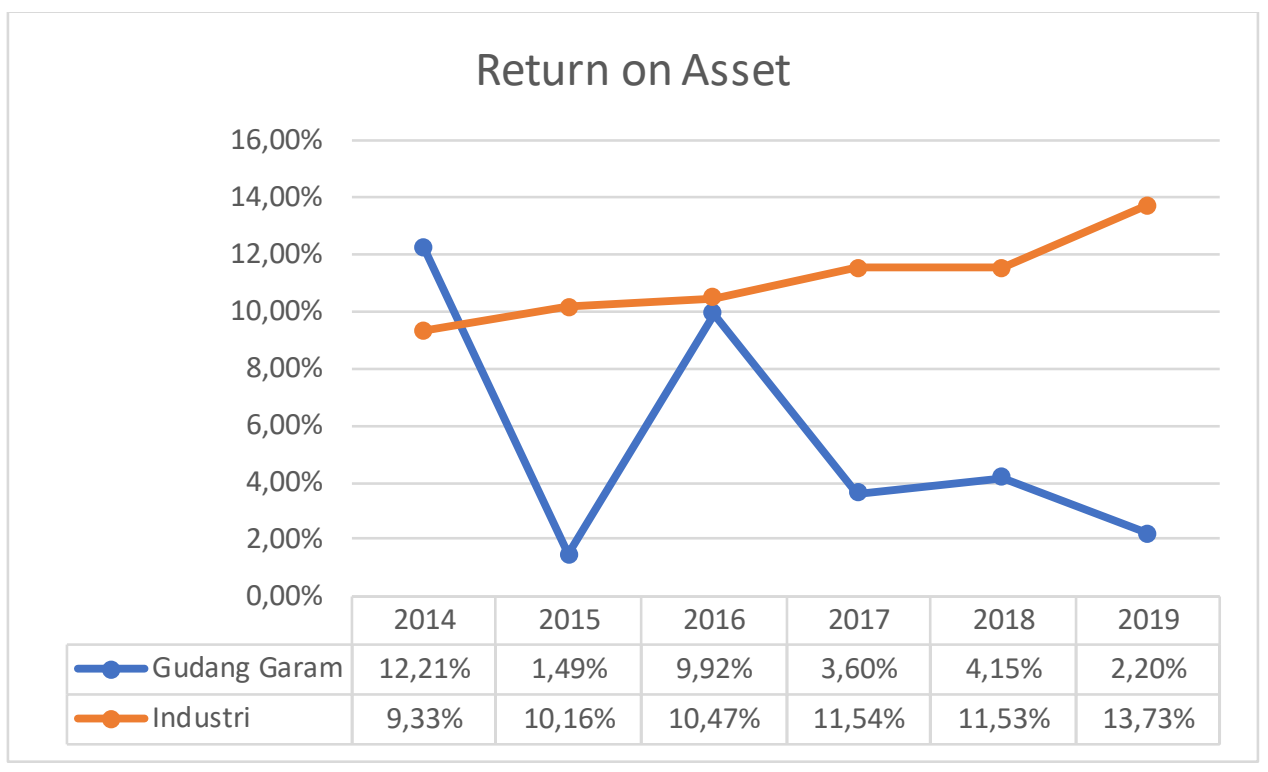

\section{Grafik 11 Perbandingan Return On Asset Gudang Garam dan Industrinya}

Return on asset dapat menunjukan persentase keuntungan (net margin) yang diperoleh perusahaan sehubungan dengan keseluruhan sumber daya atau rata-rata jumlah asset atau seberapa besar keuntungan yang dapat diperoleh atau dihasilkan perusahaan dari asset yang dimiliki perusahaan. Semakin tinggi nilai return on asset maka semakin tinggi pula laba yang dihasilkan perusahaan dari asset yang dimiliki oleh perusahaan.

Sesuai dengan gambar grafik diatas maka return on asset PT Gudang Garam Tbk bandingkan dengan Total Industri Tobacco berbeda-beda setiap tahun. Maka untuk mengetahui hasil yang lebih akurat dapat dilakukan dengan menjumlahkan nilai rata-rata return on asset selama enam tahun. Untuk hasil rata-rata nilai return on asset PT Gudang Garam Tbk. sebesar 3,07\% sedangkan Total Industri Tobacco 5,78\%. Sehingga dapat disimpulkan dimana nilai return on asset PT Gudang Garam Tbk. berada pada posisi lebih tinggi di bandingkan dengan Total Industri Tobacco. Maka dapat disimpulkan bahwa PT Gudang Garam Tbk lebih baik di bandingkan Total Industri Tobacco. 


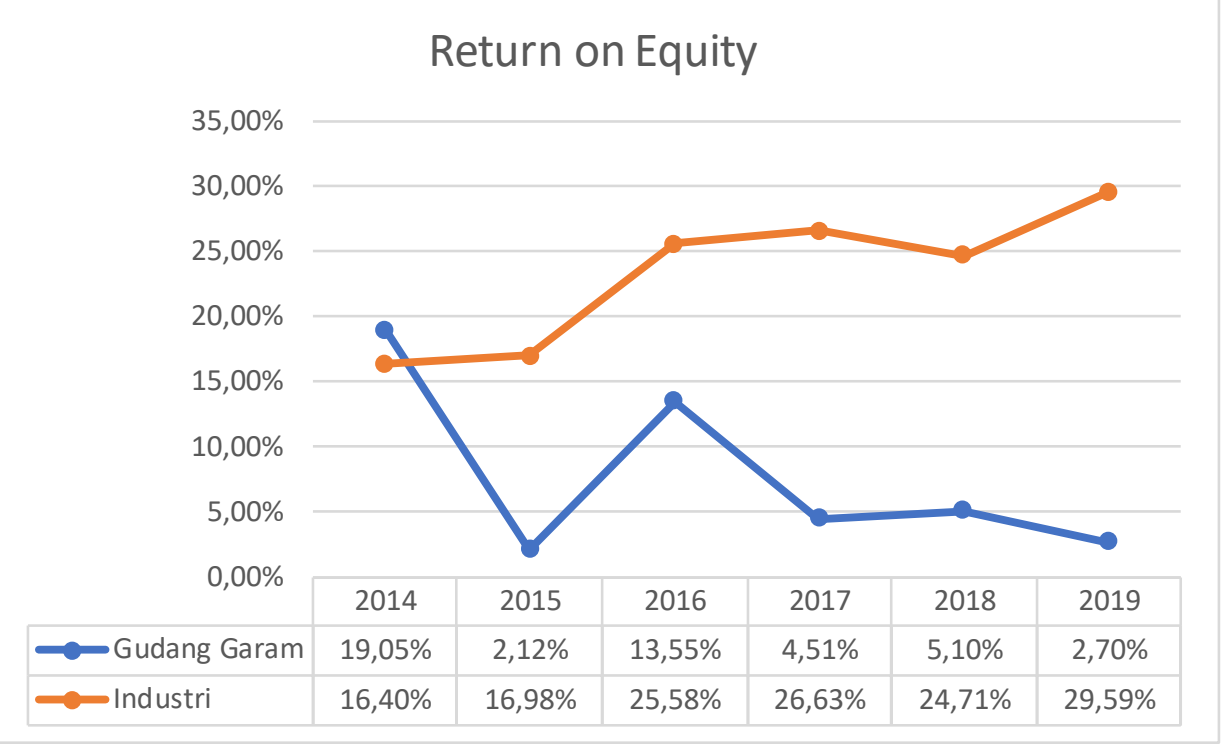

\section{Grafik 12 Perbandingan Return On Equity Gudang Garam dan Industrinya}

Return on equity atau pengembalian ekuitas atau ROE (Return On Equity) dimana salah satu perhitungan yang masuk dalam rasio profitabilitas. Untuk perusahaan digunakan untuk mengukur kemampuan dalam menghasilkan laba dengan bermodalkan ekuitas yang sudah diinvestasikan pemegang saham

Sesuai dengan gambar grafik diatas maka return on equity PT Gudang Garam Tbk dibandingkan dengan Total Industri Tobacco berbeda-beda setiap tahun. Sehingga untuk mengetahui hasil yang lebih akurat dapat dilakukan dengan menjumlahkan nilai rata-rata return on equity selama enam tahun. Untuk hasil rata-rata nilai return on equity PT Gudang Garam Tbk sebesar 12,19\% sedangkan Total Industri Tobacco sebesar 24,18\%. Maka dapat disimpulkan dimana nilai return on equity PT Gudang Garam Tbk berada pada posisi lebih rendah di bandingkan dengan Total Industri Tobacco. Sehingga jika disimpulkan bahwa PT. Gudang Garam Tbk lebih baik di bandingkan Total Industri Tobacco.

Tabel 3. Analisis Du Pont

\begin{tabular}{|c|c|c|c|c|c|c|c|c|c|c|c|c|}
\hline \multirow[b]{2}{*}{ Jenis Ratio } & \multicolumn{2}{|c|}{2014} & \multicolumn{2}{|c|}{2015} & \multicolumn{2}{|c|}{2016} & \multicolumn{2}{|c|}{2017} & \multicolumn{2}{|c|}{2018} & \multicolumn{2}{|c|}{2019} \\
\hline & $\begin{array}{l}\text { Gudang } \\
\text { Garam } \\
\end{array}$ & Industri & $\begin{array}{l}\text { Gudang } \\
\text { Garam } \\
\end{array}$ & Industri & \begin{tabular}{|l} 
Gudang \\
Garam \\
\end{tabular} & Industri & Gudang Garam & Industri & $\begin{array}{l}\text { Gudang } \\
\text { Garam } \\
\end{array}$ & Industri & $\begin{array}{l}\text { Gudang } \\
\text { Garam } \\
\end{array}$ & Industri \\
\hline Profit Margin & $8.33 \%$ & $9.79 \%$ & $9.17 \%$ & $1.09 \%$ & $8.75 \%$ & $7.97 \%$ & $11.53 \%$ & $2.99 \%$ & $8.32 \%$ & $3.71 \%$ & $9.70 \%$ & $2,05 \%$ \\
\hline Total Aset Turnover & 1.12 & 1,24 & 1.11 & 1,36 & 1.21 & 1,24 & 1.25 & 1,17 & 1.39 & 1,11 & 1.41 & 1,07 \\
\hline Equality Multiplier & 1.76 & 1,56 & 1.67 & 1,42 & 1.59 & 1,36 & 1.59 & 1,28 & 1.53 & 1,24 & 1.54 & 1,25 \\
\hline ROE Analisis DuPont & $16.40 \%$ & $19.05 \%$ & $16.98 \%$ & $2.12 \%$ & $25.58 \%$ & $13.55 \%$ & $26.63 \%$ & $4.51 \%$ & $24.71 \%$ & $5.10 \%$ & $29.59 \%$ & $2.70 \%$ \\
\hline
\end{tabular}

Sumber: Laporan Keuangan Tahunan PT Gudang Garam Tbk . (https://www.gudanggaramtbk.com/media/uploads/files/GGRM_AR_2019 FINAL.pdf) 


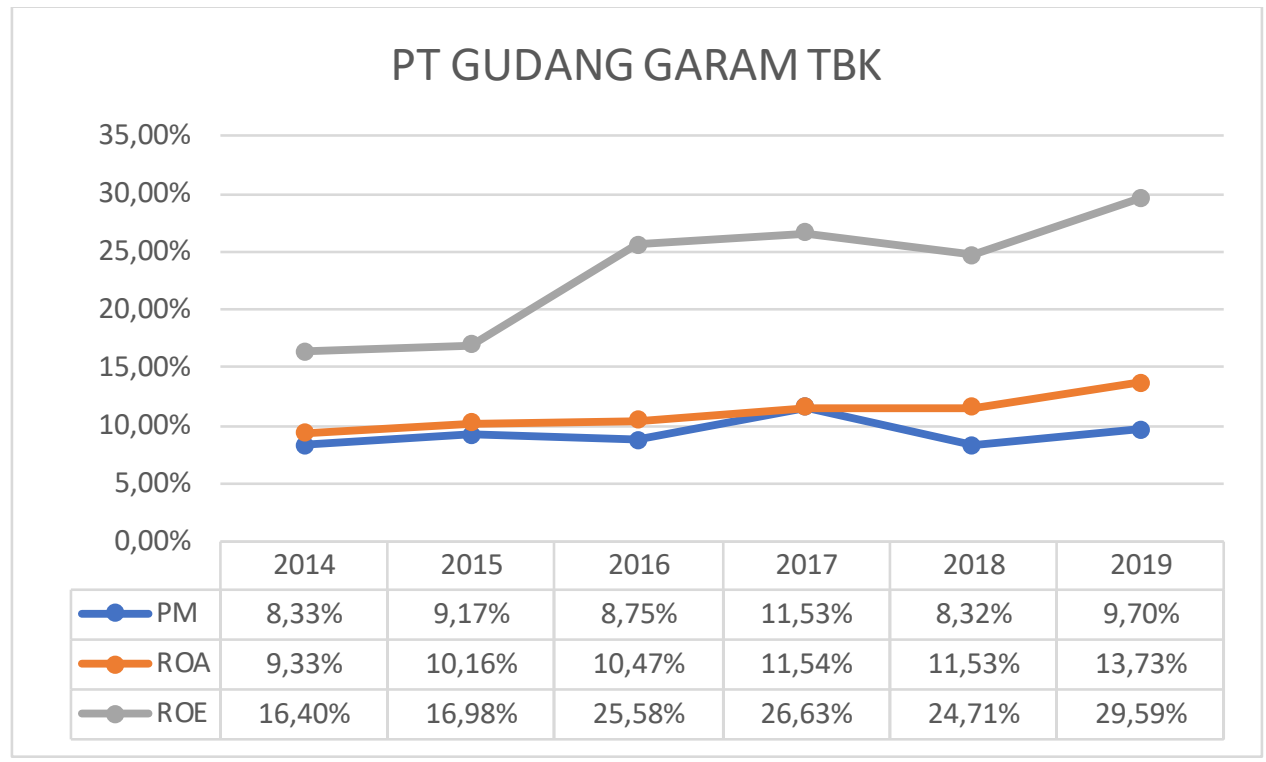

\section{Grafik 13 Perbandingan Profit Margin, Return On Asset, \& Return On Equity Gudang Garam}

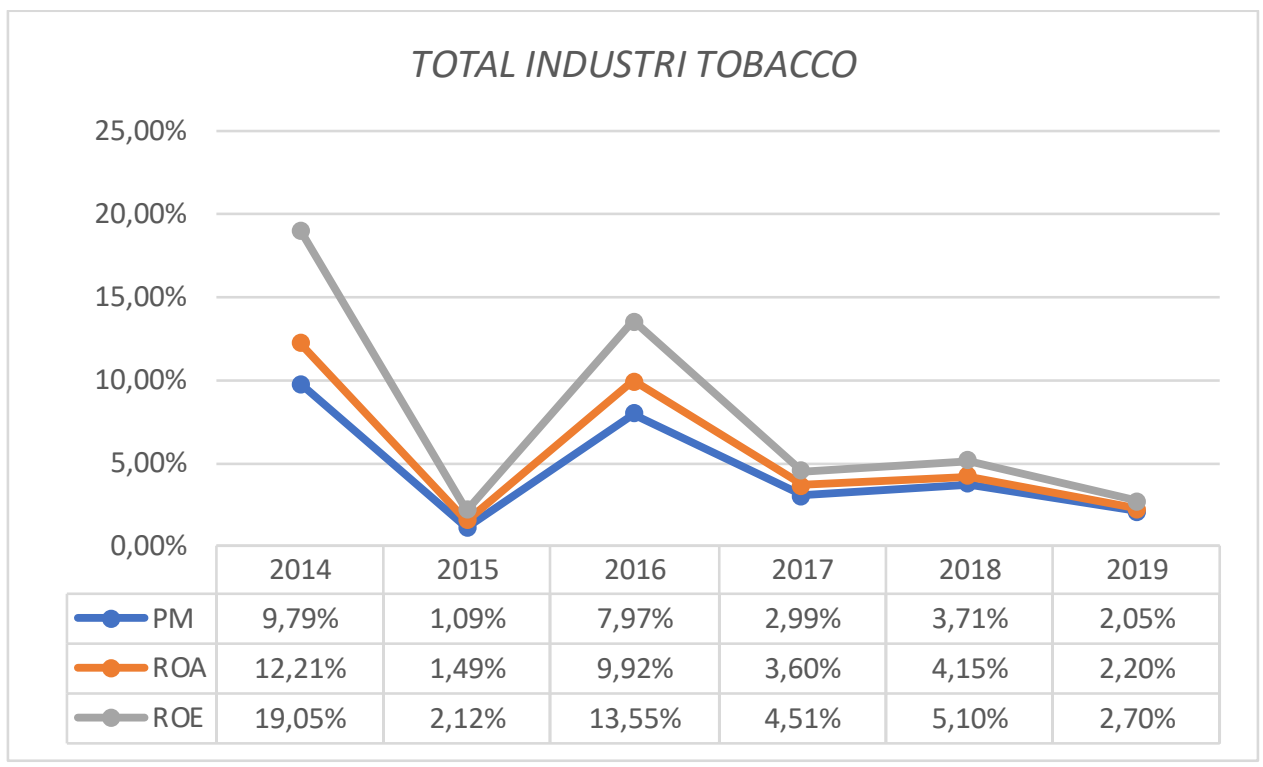

\section{Grafik 14 Perbandingan Profit Margin, Return On Asset, \& Return On Equity Industrinya}

Sesuai dengan gambar grafik 13 dan 14 dimana profit margin, return on asset, \& return on equity PT Gudang Garam Tbk, dibandingkan dengan total Industri Tobacco berbeda-beda setiap tahun. Sehingga untuk mengetahui hasil yang lebih akurat akan dilakukan dengan menjumlahkan rata-rata nilai profit margin, return on asset, \& return on equity selama enam tahun. Untuk hasil rata-rata nilai profit margin, return on asset, \& return on equity PT Gudang Garam Tbk. sebesar 11,5\% sedangkan total industri industri Tobacco sebesar 11,7\%. Maka dapat disimpulkan bahwa nilai profit margin, return on asset, \& return on equity PT Gudang Garam Tbk berada pada 
posisi lebih tinggi di bandingkan dengan total industri Tobacco. Sehingga dapat disimpulkan bahwa PT Gudang Garam Tbk lebih baik di bandingkan total industri Tobacco.

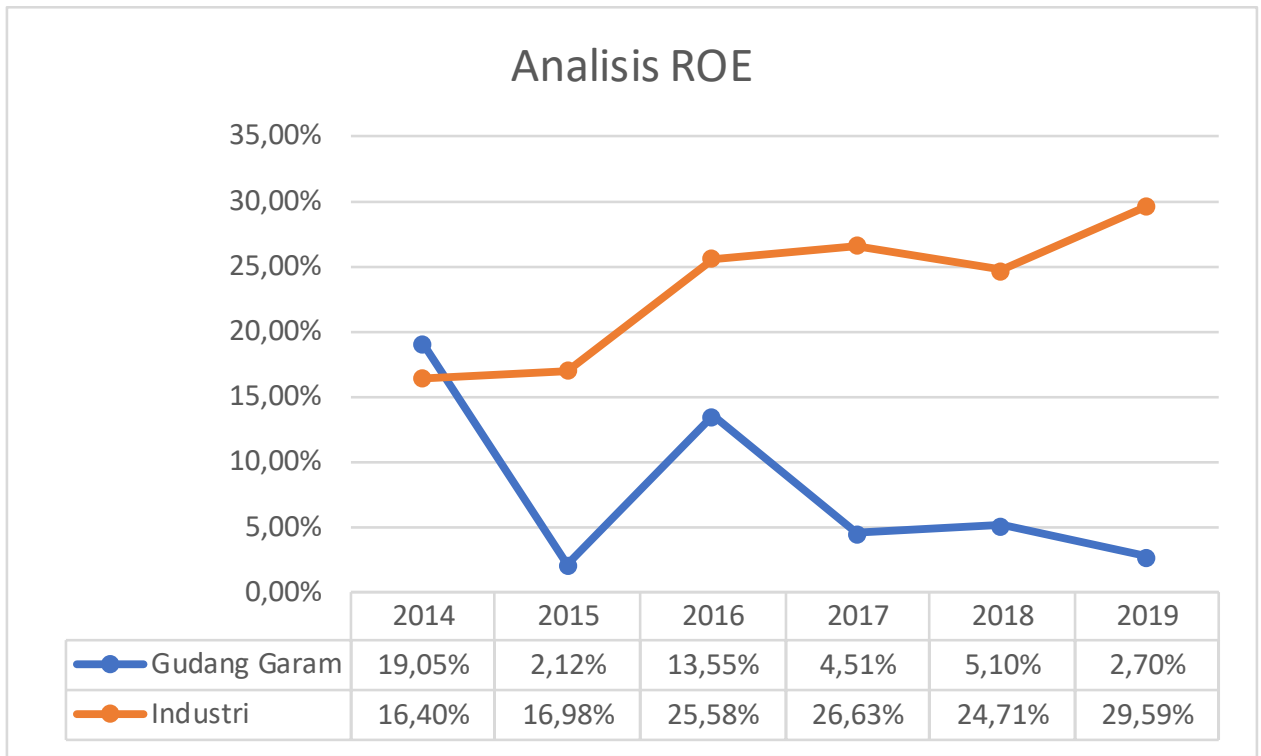

\section{Grafik 15 Perbandingan Return On Equity Gudang Garam dan Industrinya}

Sesuai dengan gambar grafik diatas dapat melihat bahwa analisis return on equity DuPont PT Gudang Garam Tbk dibandingkan dengan total industri Tobacco berbeda-beda setiap tahun. Sehingga untuk mengetahui hasil yang lebih akurat dapat dilakukan dengan menjumlahkan nilai rata-rata analisis return on equity DuPont selama enam tahun. Untuk hasil rata-rata nilai analisis return on equity DuPont PT Gudang Garam Tbk, sebesar 14,15\% sedangkan total industri Tobacco sebesar $15,02 \%$. Maka dapat disimpulkan bahwa nilai analisis return on equity DuPont PT Gudang Garam Tbk. berada pada posisi lebih rendah di bandingkan dengan total industri Tobacco. Sehingga dapat disimpulkan bahwa total industri Tobacco lebih baik di bandingkan PT Gudang Garam Tbk.

\section{KESIMPULAN}

Sesuai dengan hasil analisis rasio PT Gudang Garam Tbk, komparatif dengan industry Tobacco yang telah dilakukan maka dapat diperoleh kesimpulan sebagai berikut :

- Current ratio industri Tobacco lebih baik dibandingkan dengan PT Gudang Garam Tbk..

- Quick ratio industri Tobacco lebih baik dibandingkan dengan PT Gudang Garam Tbk.

- Total debt ratio industri Tobacco lebih baik dibandingkan dengan PT Gudang Garam Tbk.

- Debt equity ratio Industri Tobacco lebih baik dibandingkan dengan PT Gudang Garam Tbk..

- Capital structure PT Gudang Garam Tbk. lebih baik dibandingkan dengan industri Tobacco.

- Receivable turnover PT Gudang Garam Tbk. lebih baik dibandingkan dengan industri Tobacco.

- Day's sale in receivable PT Gudang Garam Tbk. lebih baik dibandingkan dengan industri Tobacco. 
- Inventory turnover Industri Tobacco. lebih baik dibandingkan dengan PT Gudang Garam Tbk.

- Total asset turnover PT Gudang Garam Tbk. lebih baik dibandingkan dengan industri Tobacco.

- Profit margin PT Gudang Garam Tbk. lebih baik dibandingkan dengan industri Tobacco.

- Return on asset PT Gudang Garam Tbk. lebih baik dibandingkan dengan industri Tobacco.

- Return on equity PT. Gudang Garam Tbk lebih baik dibandingkan dengan industri Tobacco.

- Return on equity DuPont industri Tobacco lebih baik dibandingkan dengan PT. Gudang Garam Tbk.

Dari 13 analisis rasio laporan keuangan yang teliti maka kesimpulan secara keseluruhan adalah PT Gudang Garam Tbk. Lebih baik mengungguli industri Tobacco.

\section{DAFTAR PUSTAKA}

Weston, F.J., dan Brigham, E.F., (1991), Dasar-Dasar Manajemen Keuangan, Diterjemahkan oleh: Khalid, Edisi Ketujuh, Jilid 2, Erlangga Jakarta.

Kasmir. 2010. Pengantar Manajemen Keuangan. Jakarta: Kencana Prenada Media Group.

Sugiyono. 2014. Metode Penelitian Kuantitatif Kualitatif dan R\&D. Bandung: Alfabeta.

Harahap, S. S. 2009. Analisis Kritis Atas Laporan Keuangan. PT. Raja Grafindo Persada. Jakarta.

Bringham, Eugene F. and Houston, Joel F. (2001). Fundamentals of Financial Management. Ohio: South-Western

Harahap, Analisis Kritis Atas Laporan Keuangan. (Jakarta: Raja Grafindo Persada, edisi Pertama, cetakan ketiga, 2007)

Weston J. Fred dan Eugene F. Brigham. 1993. Dasar-dasar Manajemen Keuangan, Jilid 2, Edisi Kesembilan, Terjemahan oleh Alfonsus Sirait, Jakarta: Erlangga

Salvatore, Dominick.2005. Managerial Economics. Fifth Edition. Singapore: Thomson Learning Sugiyono, (2008). Metode Penelitian Kunatitatif Kualitatif dan R\&D. Bandung Alfabeta.

Ikatan Akuntan Indonesia (IAI), (2009:1), Standar Keungan Akutansi. Salemba Empat, Jakarta

Irawati, S. 2005. Manajemen Keuangan. Bandung: Penerbit Pustaka 